\title{
Snow-Depth and Water-Equivalent Data for the \\ Fairbanks Area, Alaska, Spring 1995
}

By Edward W. Plumb and Michael R. Lilly

U.S. GEOLOGICAL SURVEY

Open-File Report 96-414

Prepared in cooperation with the

FAIRBANKS INTERNATIONAL AIRPORT

UNIVERSITY OF ALASKA FAIRBANKS

ALASKA DEPARTMENT OF NATURAL RESOURCES

DIVISION OF MINING AND WATER MANAGEMENT

U.S. ARMY, ALASKA

and

U.S. ARMY CORPS OF ENGINEERS, ALASKA DISTRICT

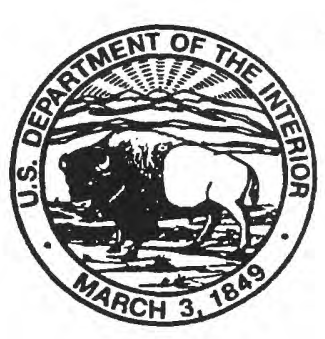

Fairbanks, Alaska 1996 


\title{
U.S. DEPARTMENT OF THE INTERIOR \\ BRUCE BABBITT, Secretary
}

\author{
U.S. GEOLOGICAL SURVEY \\ Gordon P. Eaton, Director
}

For additional information write to:

District Chief

U.S. Geological Survey

4230 University Drive, Suite 201

Anchorage, Alaska 99508-4664
Copies of this report may be purchased from:

U.S. Geological Survey

Branch of Information Services

Box 25286

Denver, Colorado 80225-0286

http://boatdakanc.wr.usgs.gov/index.html 


\section{CONTENTS}

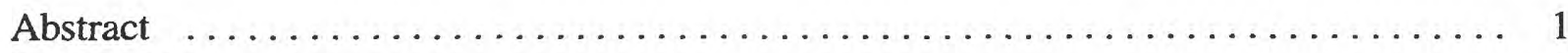

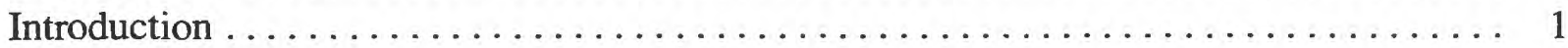

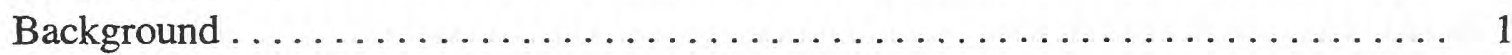

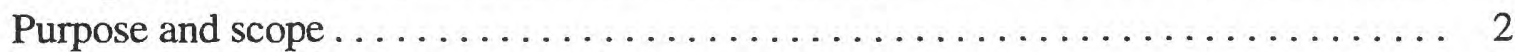

Location and description of the study area $\ldots \ldots \ldots \ldots \ldots \ldots \ldots \ldots \ldots \ldots$

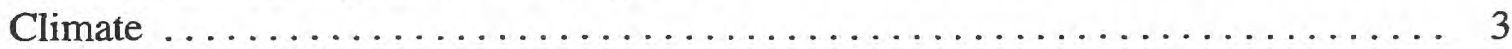

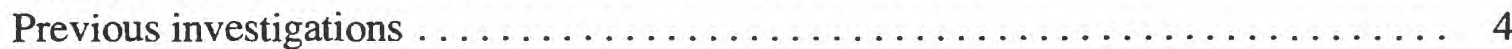

Data-collection sites. . . . . . . . . . . . . . . . . . . . . . 4

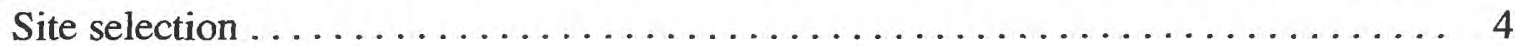

Site classification. . . . . . . . . . . . .

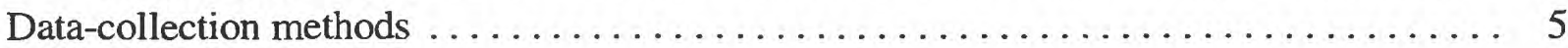

Snow depths. . . . . . . . . . . . . . . . . . . $5 \ldots \ldots \ldots \ldots \ldots$

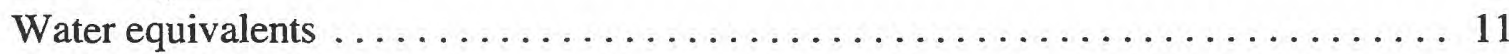

Error analysis. . . . . . . . . . . . . . . 11

Supplemental data . . . . . . . . . . . . . . . . . . . . 11

Snow depths and water equivalents. . . . . . . . . . . . . . . 11

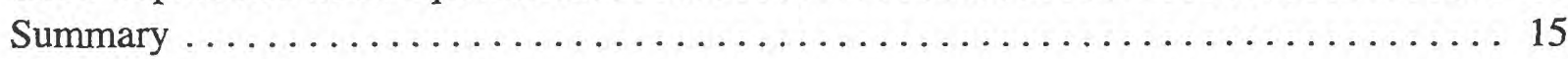

References cited................................... 15

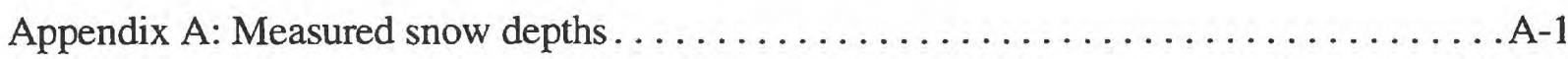

Appendix B: Measured snow depths and water equivalents . . . . . . . . . . .

\section{FIGURES}

1. Map showing location of Fairbanks area study sites $\ldots \ldots \ldots \ldots \ldots \ldots \ldots$

2. Map showing snow-depth and water-equivalent data-collection sites,

Fairbanks, Alaska . . . . . . . . . . . . . . . . 6

3. Photographs of examples of data-collection sites: a) open, b) boggy, c) wooded,

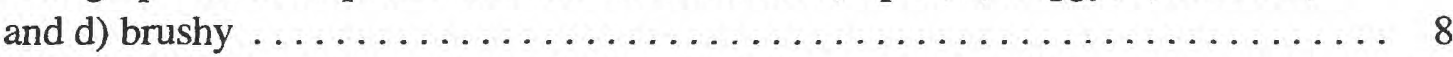

4. Snowpack depth change at open, boggy, wooded, and brushy sites . . . . . . . 14

5. Snowpack depth and water-equivalent change at open and wooded sites . . . . . 14

\section{TABLES}

1. Mean monthly temperature, precipitation, and snowfall data for Fairbanks,

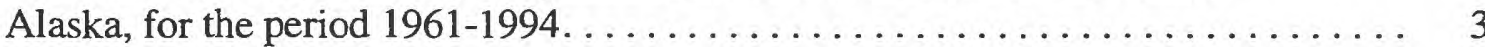

2. Average snow depths measured with yardstick, Fairbanks, Alaska, spring 1995 . . . 9

3. Average snow depths and water equivalents measured with Adirondack snow sampling tube at selected sites, Fairbanks, Alaska, spring 1995 . . . . . . . . . . 12

4. Supplemental snow-depth measurements in the Fairbanks area, Alaska, spring 1995. . 13 


\begin{tabular}{rlll}
\hline Multiply & By & To obtain \\
\hline inch (in.) & 25.4 & millimeter \\
inch (in.) & 2.54 & centimeter \\
foot (ft) & 0.3048 & meter \\
mile (mi) & 1.609 & kilometer \\
& & \\
\hline
\end{tabular}

In this report, temperature is reported in degrees Fahrenheit $\left({ }^{\circ} \mathrm{F}\right)$, which can be converted to degrees Celsius $\left({ }^{\circ} \mathrm{C}\right)$ by the following equation: ${ }^{\circ} \mathrm{C}=\left({ }^{\circ} \mathrm{F}-32\right) / 1.8$

Horizontal Datum:

The horizontal datum for all locations in this report is the North American datum of 1927. 


\title{
Snow-Depth and Water-Equivalent Data for the Fairbanks Area, Alaska, Spring 1995
}

\author{
By Edward W. Plumb and Michael R. Lilly
}

\begin{abstract}
Snow depths at 34 sites and snow-water equivalents at 13 sites in the Fairbanks area were monitored during the 1995 snowmelt period (March 30 to April 26) in the spring of 1995. The U.S. Geological Survey conducted this study in cooperation with the Fairbanks International Airport, the University of Alaska Fairbanks, the Alaska Department of Natural Resources-Division of Mining and Water Management, the U.S Army, Alaska, and the U.S. Army Corps of EngineersAlaska District. These data were collected to provide information about potential recharge of the ground-and surface-water systems during the snowmelt period in the Fairbanks area. This information is needed by companion geohydrologic studies of areas with known or suspected contaminants in the subsurface. Data-collection sites selected had open, boggy, wooded, or brushy vegetation cover and had different slope aspects.
\end{abstract}

The deepest snow at any site, 27.1 inches, was recorded on April 1, 1995; the shallowest snow measured that day was 19.1 inches. The snow-water equivalents at these two sites were 5.9 inches and 4.5 inches, respectively. Snow depths and water equivalents were comparatively greater at open and bog sites than at wooded or brushy sites. Snow depths and water equivalents at all sites decreased throughout the measuring period. The decrease was more rapid at open and boggy sites than at wooded and brushy sites. Snow had completely disappeared from all sites by April 26, 1995.

\section{INTRODUCTION}

\section{Background}

The U.S. Geological Survey (USGS) is conducting geohydrologic investigations in the Fairbanks area to assist other government agencies in understanding the movement of ground water at sites of known and suspected subsurface contamination. The timing and amount of recharge may affect the distribution of contaminants in unsaturated soils and their transport to the shallow watertable aquifer in the alluvial plain. In order to better understand the contribution of snowmelt to the ground-water system, snow depth and water content of the snowpack were measured. Data were collected by the USGS under cooperative programs with the Fairbanks International Airport, the University of Alaska Fairbanks (UAF), the Alaska Department of Natural Resources-Division of Mining and Water Management, the U.S Army, Alaska, and the U.S. Army Corps of EngineersAlaska District. 


\section{Purpose and Scope}

The purpose of this study was to characterize-by the vegetation cover-the snow depth, water content, and melting rate of the snowpacks at four study areas in the vicinity of Fairbanks, Alaska (fig. 1). Snow depths were repeatedly measured at 34 sites, and water equivalents at 13 of these sites, during spring 1995 to document the degradation of the snowpack through the melting period. Water-equivalent measurements may be integrated with area to estimate the changing volume of water stored on the land surface. Water available at the soil surface may recharge the ground- and surface-water systems through infiltration or runoff. This information may be used in future efforts to model the timing and distribution of aquifer recharge and to track possible distribution of contaminants in the ground- and surface-water systems in the Fairbanks area. This report presents the snow-depth and water-equivalent data that were collected during this investigation. Data cover the period from maximum winter snowpack until the completion of melting at all collection sites except at nine sites at which data collection started after the onset of melting. This resulted in a less than maximum snow depth at these sites, but no loss of water equivalent.

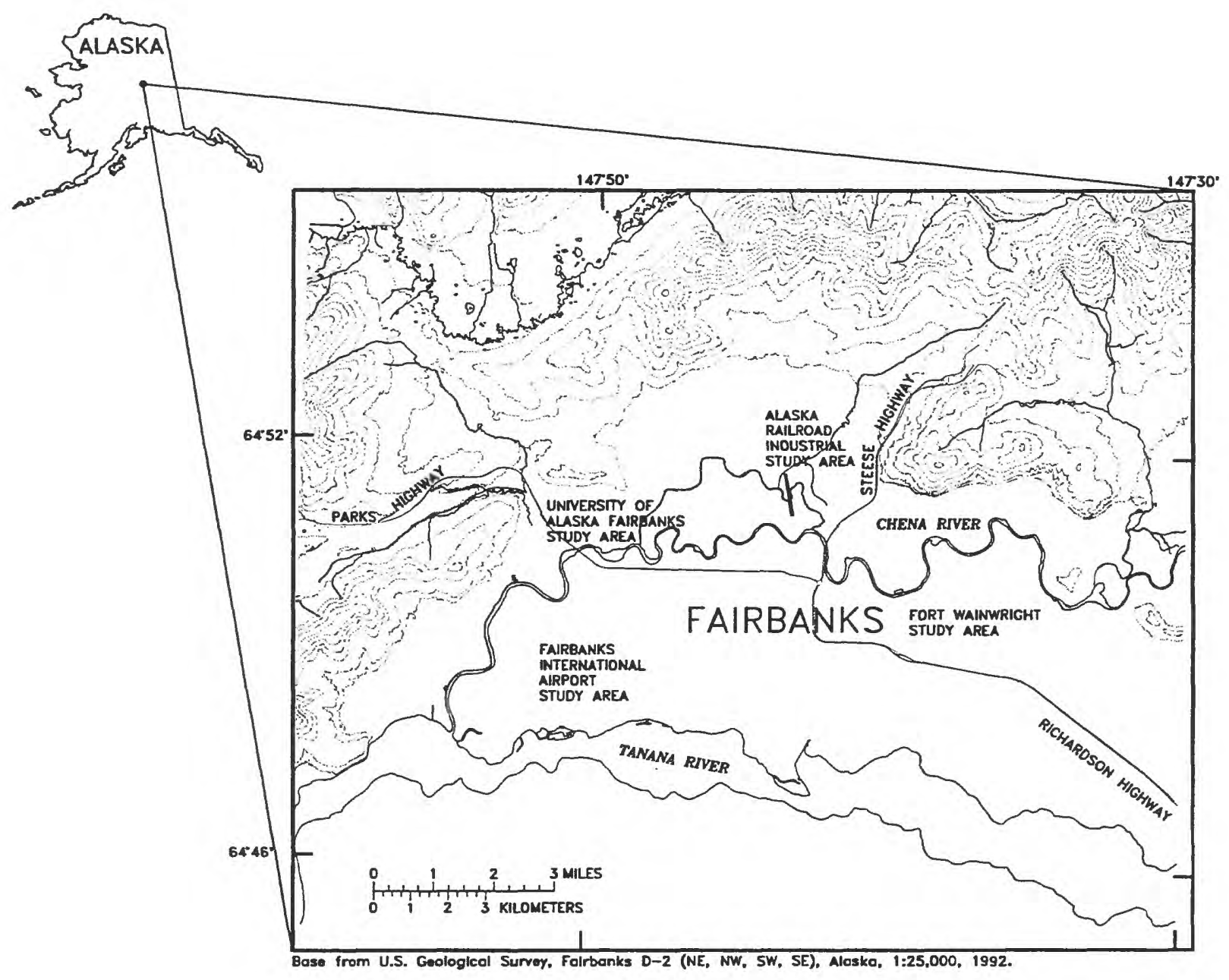

Figure 1. Location of Fairbanks area study sites. 


\section{Location and Description of the Study Area}

Fairbanks (fig. 1) is located in the interior of Alaska, approximately 100 miles south of the Arctic Circle and 55 miles north of the Alaska Range. It is situated on the Chena River, upstream from its confluence with the Tanana River. The city is bounded by hills of the Yukon-Tanana Upland (Anderson, 1970) to the west, north, and east, and by the broad alluvial plain of the Tanana River to the south. The data-collection area extends from the Fairbanks International Airport to Fort Wainwright, including Fairbanks and Birch Hill, and includes the hills northeast of the city (fig. 1). The area is dominated by coniferous and deciduous trees of the northern boreal forest, except in areas that have been developed and stripped of native vegetation.

\section{Climate}

Fairbanks has a distinctly continental climate characterized by large seasonal temperature variations. For example, the 1961-94 mean monthly temperature for January at the Fairbanks International Airport is $-9.3^{\circ} \mathrm{F}$, in contrast with the mean monthly temperature for July of $62.6^{\circ} \mathrm{F}$ (table 1). These variations are caused by fluctuations in solar radiation received by the region throughout the year. The mountain ranges that lie to the south and north serve as climate barriers, sheltering Fairbanks from maritime influences and severe winds (National Oceanic and Atmospheric Administration (NOAA), 1978).

Table 1. Mean monthly temperature, precipitation, and snowfall data for Fairbanks, Alaska, for the period 1961-1994

[Temperature in degrees Fahrenheit; precipitation in equivalent inches of water; snowfall values in inches of snow. All data recorded at Fairbanks International Airport for the period 1961-1994. Data from NOAA (1994)]

\begin{tabular}{cccc}
\hline Month & $\begin{array}{c}\text { Average } \\
\text { Temperature }\end{array}$ & $\begin{array}{c}\text { Average } \\
\text { Precipitation }\end{array}$ & $\begin{array}{c}\text { Average } \\
\text { Snowfall }\end{array}$ \\
\hline January & -9.3 & 0.56 & 10.4 \\
February & -3.6 & 0.39 & 8.4 \\
March & 11.3 & 0.41 & 6.9 \\
April & 31.1 & 0.30 & 3.7 \\
May & 48.7 & 0.60 & 0.9 \\
June & 60.0 & 1.39 & 0.0 \\
July & 62.6 & 1.79 & 0.0 \\
August & 56.7 & 1.87 & 0.0 \\
September & 45.1 & 1.01 & 1.8 \\
October & 25.2 & 0.96 & 11.8 \\
November & 2.9 & 0.82 & 15.7 \\
December & -6.3 & 0.85 & 15.1 \\
\hline Annual & 27.0 & 10.95 & 74.7 \\
\hline
\end{tabular}


Annual precipitation in the Fairbanks area is relatively light compared with conterminous United States standards, averaging 10.95 inches (table 1) during the 1961-94 period (NOAA, 1994). The dominant form of precipitation from October through April is snow. The seasonal average snowfall is 74.7 inches (table 1) for the 1961-94 period (NOAA, 1994). The variability of the seasonal snowfall can be extreme. For example, during the 1969-1970 snowfall season, 36.4 inches of snow fell at the Fairbanks International Airport compared with the 145.7 inches that fell during the following season (NOAA, 1978). The snowpack builds through the winter months and generally reaches a maximum depth during March. Accumulating snow tends to remain stationary due to the lack of strong winds during the winter. The snowpack generally persists for 6 to 7 months and has an average water content of 4 inches in the lowlands and from 6 to 8 inches in the uplands and mountains (U.S. Soil Conservation Service, 1983). For the remainder of the year, rain is the dominant form of precipitation (table 1).

In interior Alaska, including Fairbanks, the snow cover has been characterized as taiga snow by the U.S. Soil Conservation Service (1983). The most notable characteristic of taiga snow is the low-density, loosely consolidated depth hoar that makes up a significant part of the snowpack (U.S. Soil Conservation Service, 1983).

\section{Previous Investigations}

Previous measurements of snow depths, water-equivalent contents, and other snow-related studies in the Fairbanks area have been conducted by Trabant (1970), Trabant and Benson (1972), Benson and Trabant (1973), Friedman and others (1991), and Sturm (1989, 1991). Furthermore, the USDA's Natural Resources Conservation Service (NRCS--formerly SCS) issues monthly publications of Alaska snow surveys for February through June of each year. These reports contain snow-depth and water-equivalent measurements, streamflow forecasts, and regional snowpack summaries.

\section{DATA-COLLECTION SITES}

The data-collection sites were selected to characterize the depth and water-content distribution of the snowpack at geohydrologic study sites in the Fairbanks area (fig. 2). Sampling density increases from west to east in the study area. The highest concentration of sites is located in the vicinity of Birch Hill and Fort Wainwright to aid USGS geohydrologic studies in that area.

\section{Site Selection}

Sampling sites were selected at each geohydrologic study area to obtain representative samples over different vegetation and slope aspects. Surface vegetation plays a major role in the evolution of the snowpack throughout the season. Open fields and boggy areas have greater snow accumulation on the ground than densely wooded and brushy areas which are more likely to suspend snow above the ground on branches. The contribution of this suspended snow to the total snowmelt volume is not addressed in this report. Slope aspect is also an important factor affecting the snowpack throughout the season. South-facing slopes are exposed to more solar radiation than north-facing slopes. At high latitudes, this radiation effect is exaggerated by the sun's low incidence angle, resulting in much higher rates of sublimation, evaporation, and melting on south-fac- 
ing slopes. While slope aspect is not considered in the discussion of the data, the slope aspects of the data-collection sites are included with the site information in appendixes A and B.

Twenty-one of the 34 sites were adjacent to USGS ground-water monitoring wells where horizontal state plane coordinates are available. The remaining 13 sites were near the USGS Fairbanks field office, UAF meteorological stations on Birch Hill, and other locales on and north of Birch Hill. Coordinates for these 13 sites, estimated from the Fairbanks D-2SE quadrangle maps, are adequate for the purposes of this report.

\section{Site Classification}

Data-collection sites were subdivided by vegetation cover into four groups; open, boggy, wooded, or brushy (fig. 3). Sites where forest vegetation has been removed are classified as open (fig. 3a). Boggy areas are distinguished by muskeg and open black spruce forest (fig. $3 \mathrm{~b}$ ). Spruce or birch and aspen forest are characteristic of wooded sites (fig. 3c). Alder and willow thickets are classified as brushy sites (fig. 3d). This classification system has been implemented in order to give simplified descriptive categories to the types of vegetation found in the data-collection area.

\section{DATA-COLLECTION METHODS}

Snow depths and, at some sites, water equivalents were measured in a 20 by 20 -foot-square area. Measurements were made on random traverses across the site to obtain a representative sample. Sites were visited one to 11 times during the 28-day melt period (March 30 - April 26, 1995). Measurements were made until the snow cover had completely melted from the most frequently visited sites. All data in this report are listed in inch-pound units. A digital version of the data in both inch-pound and metric (SI) units is available from the District Chief, U.S. Geological Survey, 4230 University Drive, Suite 201, Anchorage, AK 99508-4664.

At each of the 13 water-equivalent data-collection sites a total of 30 snow-depth measure-

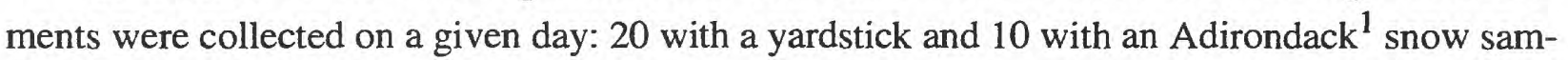
pler. The snow depths recorded with these two devices were not averaged together and are listed as separate measurements. The recorded individual measurements from the yardstick and the Adirondack snow sampler are presented in appendixes A and B, respectively. Yardstick measurements were recorded to 0.10 inch and Adirondack snow sampler measurements to the nearest inch. In general, snow-depth measurements made with the yardstick averaged slightly greater than those made with the Adirondack snow sampler.

\section{Snow Depths}

During every visit to each of the 34 data-collection sites, snow depth was measured with a yardstick at 20 locations (Appendix A). The average snow depth for each visit was calculated from the 20 individual measurements. Average snow depths for each site on a particular date are summarized in table 2 .

\footnotetext{
${ }^{1}$ The use of brand, firm, or product names in this report is for identification purposes only, and does not constitute endorsement by the U.S. Geological Survey.
} 


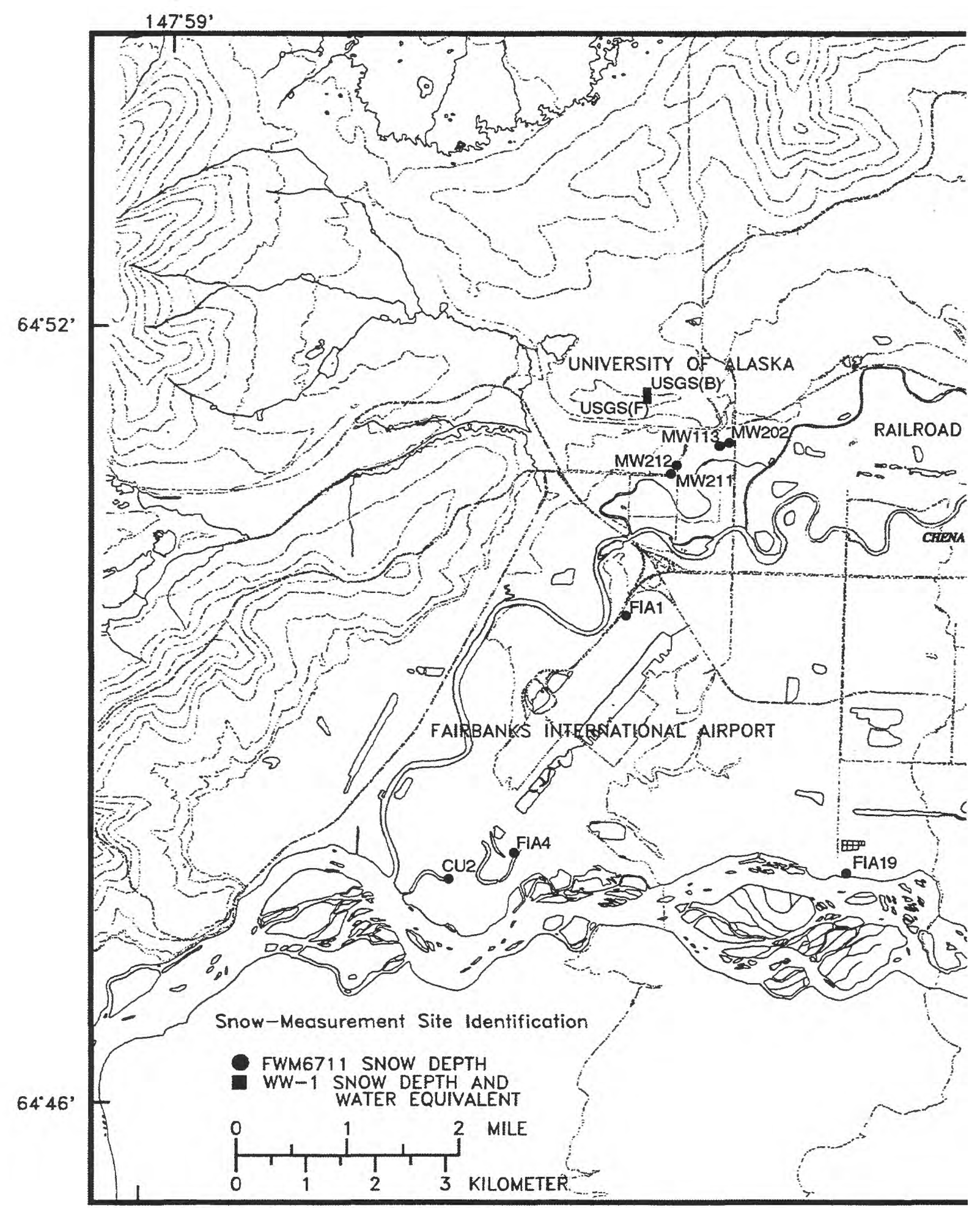

Base from U.S. Geological Survey, Fairbanks D-2 SW, D-2 NW, D-2 NE, D-2 SE, 1:25000, 1992

Figure 2. Snow depth and water-equivalent data-collection sites, Fairbanks, Alaska. 


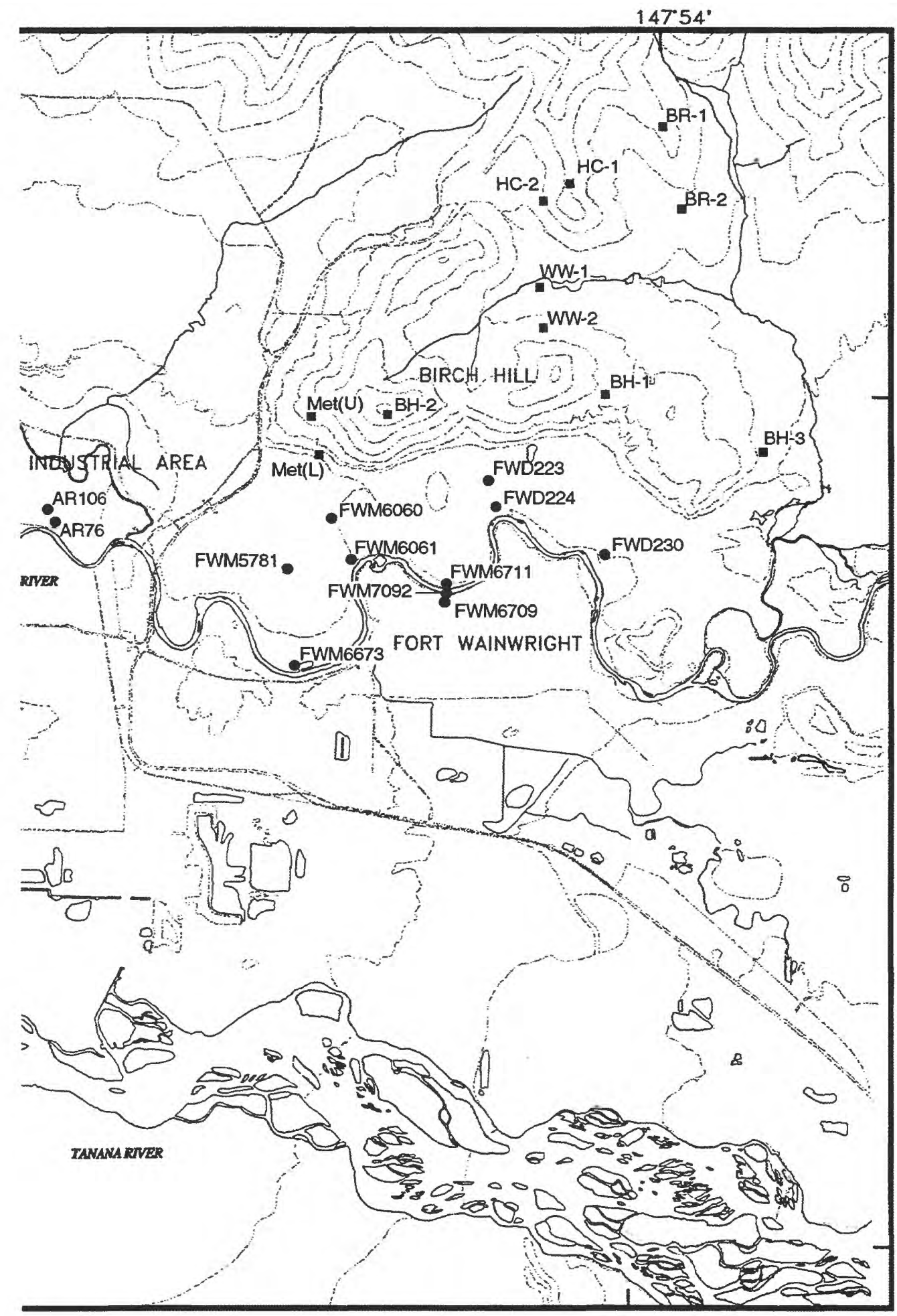



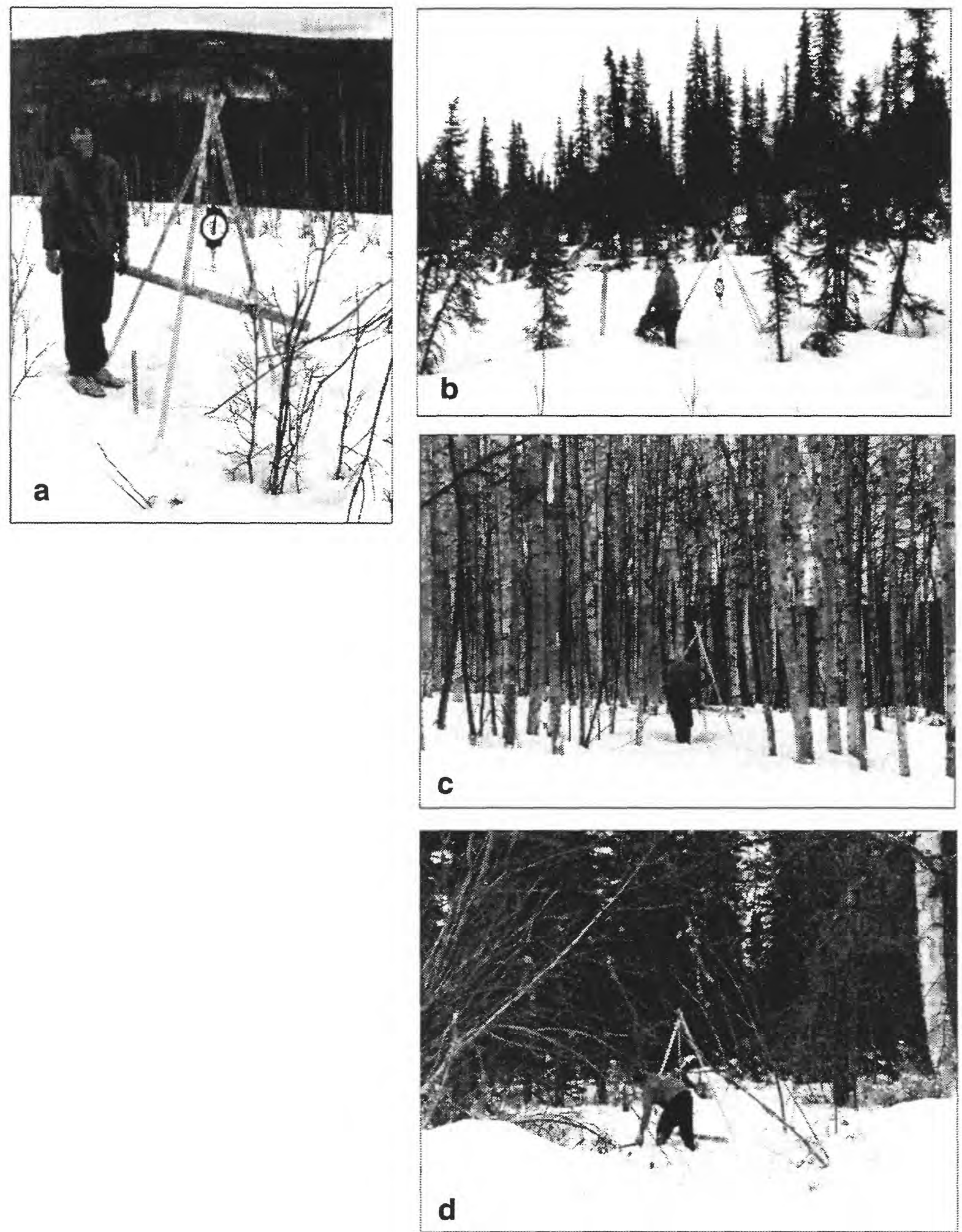

Figure 3. Examples of data collection sites: (a) open, (b) boggy, (c) wooded, and (d) brushy. 


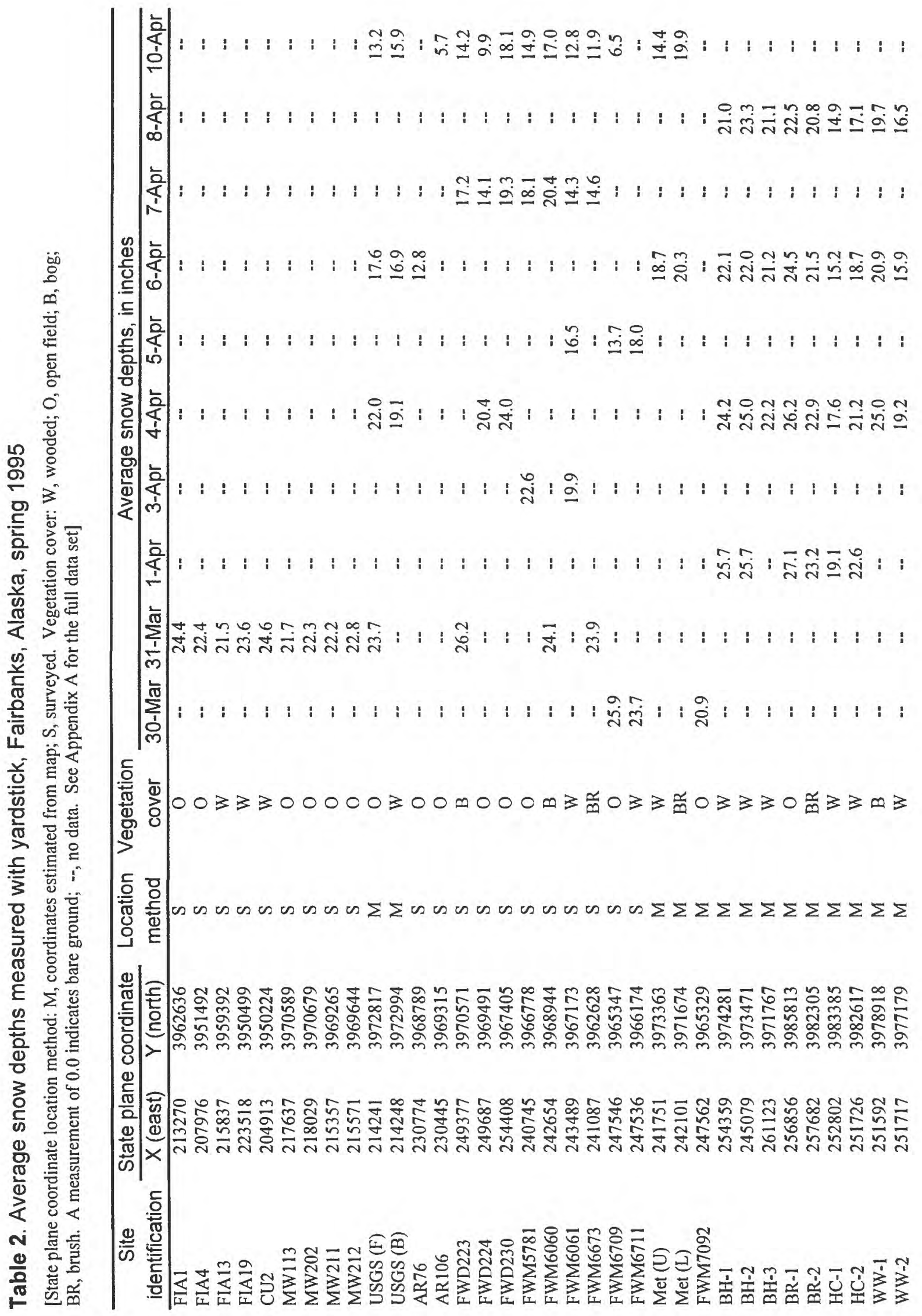




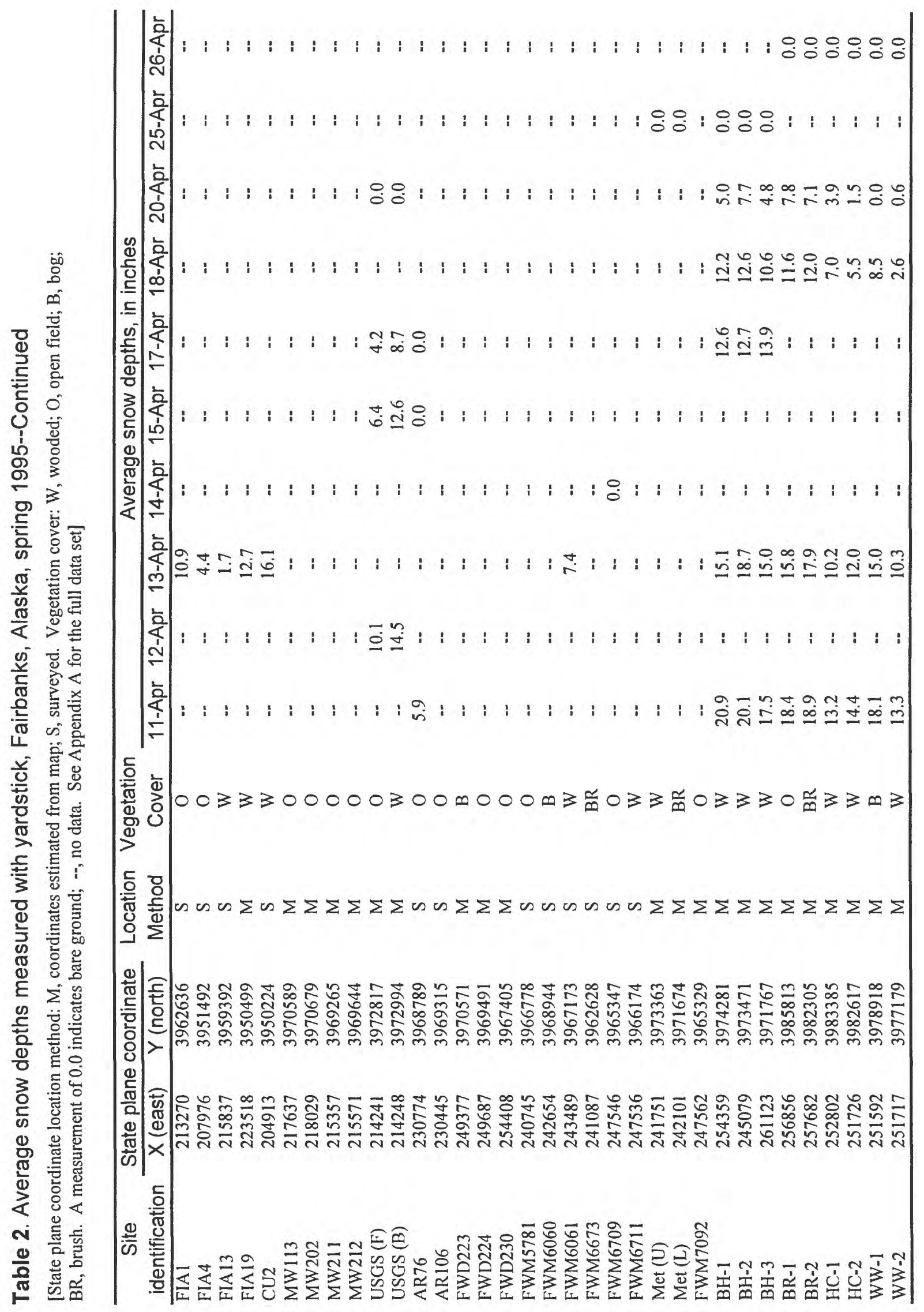




\section{Water Equivalents}

Snowpack water equivalents were measured at 13 of the 34 data-collection sites. Ter measurements at each site were made with an Adirondack snow-sampling tube marked in one-inch increments and recorded (Appendix B). The snow depth was read from the tube and the column of snow in the tube was weighed with a water-equivalent scale suspended from a tripod (fig. 3b). Average snow depths and water equivalents calculated from the 10 measurements (Appendix B) are summarized in table 3 . The water equivalent is the equivalent depth of water at the measurement point. A water volume can be evaluated by extrapolating this value to a given area.

\section{Error Analysis}

Standard deviations have been calculated for the daily recorded individual measurements from the yardstick (Appendix A) and Adirondack snow-sampling tube (Appendix B). The standard deviation varied significantly between the four distinct site groups. Open sites tend to have less error, or a smaller standard deviation, among individual measurements. This occurs because open sites are characterized by a more continuous underlying ground surface and are not obstruc ${ }^{+}$ed by vegetation compared with the boggy, wooded, and brushy sites. For the snow depths measure 1 with the yardstick, the standard deviation ranged from an error of 0.4 inch at several open sites to 5.5 inches at a wooded site. Similar comparisons are present in the measurements made with the Adirondack snow sampler.

\section{Supplemental Data}

Other sources of snow-depth data collected during this period include the Fairbanks Ir ternational Airport, the USGS College Observatory, the Fort Wainwright Airport, and the home cf Carl Benson. These data are included in this report (table 4) as supplemental data, and have not been incorporated into the summary of this report.

\section{SNOW DEPTHS AND WATER EQUIVALENTS}

The greatest average snow depth of 27.1 inches was recorded at BR-1 on April 1, 1995, and the lowest average snow depth for the same day was 19.1 inches, at HC-1 (tables 2 and 3). The snow-water equivalents at these two sites were 5.9 inches and 4.5 inches, respectively. BR-1 is located in an open field along a ridge north of Birch Hill and HC-1 is on a wooded, southwert-facing slope (fig. 2).

Rates of snowpack degradation for selected open, boggy, wooded, and brushy sites are shown in figure 4 . The open site USGS(F) and the boggy site WW-1 have the greatest snow dept'hs and the highest melting rates. HC-2 and BR-2 are wooded and brushy sites, respectively, and have relatively lower snow depths and melting rates than the open and boggy sites. The HC-2 and BR-2 snowpack degradation trends were estimated with a dashed line after April 20, 1995, becarse the snowpack had melted before the last site visit on April 26, 1995.

Average snow depths and water equivalents gradually decreased throughout the measuring period with the faster rates at open sites. USGS sites (F) and (B) provide good examples of the different snowpack melting conditions for vegetated versus non-vegetated areas (fig. 5). Site 

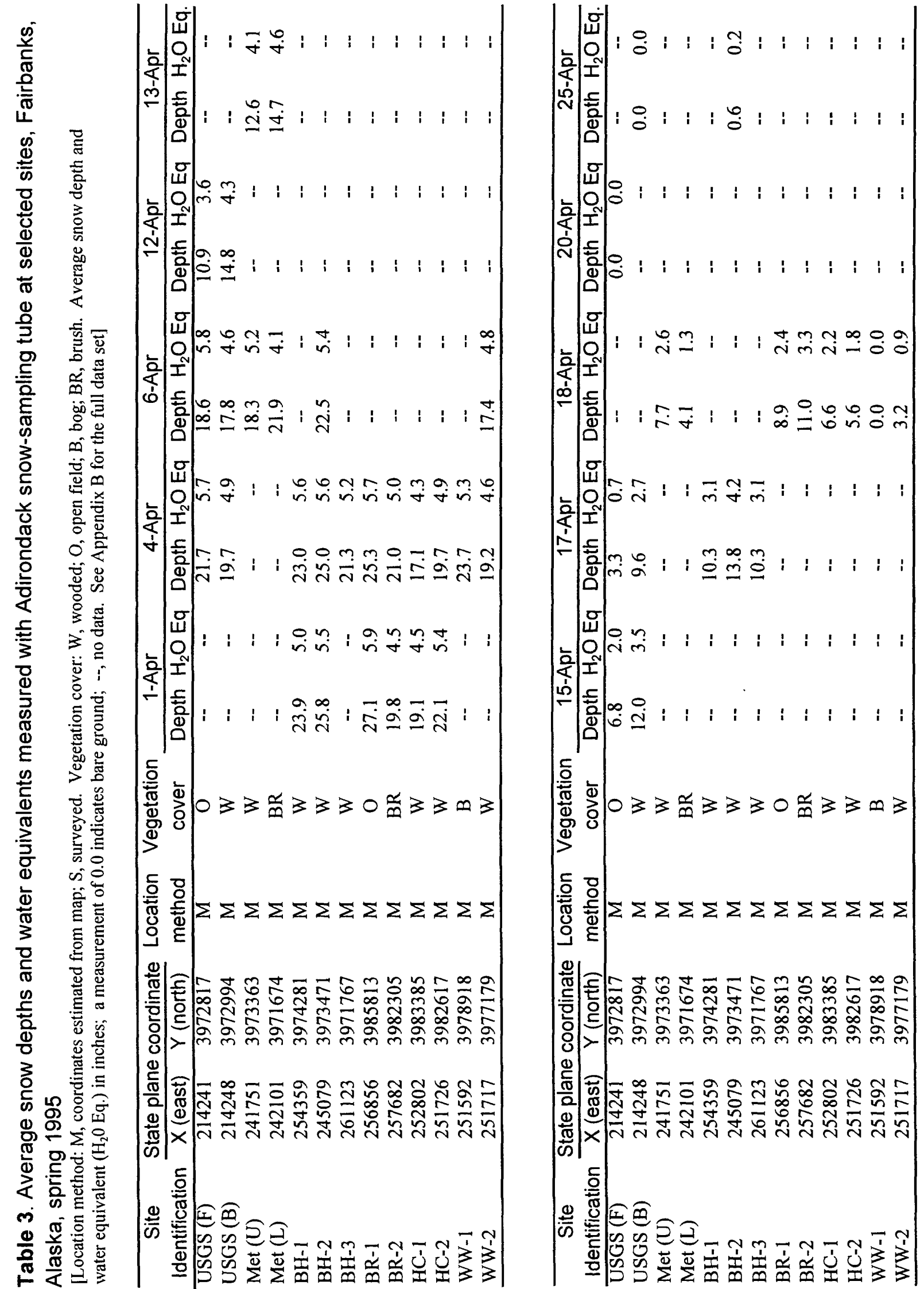
Table 4. Supplemental snow-depth measurements in the Fairbanks area, Alaska, spring 1995 [FIA, Fairbanks International Airport; College, U.S. Geological Survey College Observatory; Benson, Carl Benson home; FTWW, Fort Wainwright Airport. A measurement of $\mathrm{T}$ indicates discontinuous or less than 0.5 inch of snow cover; --, no data. Data in parentheses () are snow-depth water equivalents in inches of water]

\begin{tabular}{|c|c|c|c|c|}
\hline \multirow{2}{*}{$\begin{array}{c}\text { Measurement } \\
\text { date }\end{array}$} & \multicolumn{4}{|c|}{ Snow depth, in inches } \\
\hline & FIA & College & Benson & FTWW \\
\hline $3 / 27$ & $26(5.0)$ & 25 & 26.8 & -- \\
\hline $3 / 28$ & $26(5.9)$ & 25 & -- & 23.0 \\
\hline $3 / 29$ & $26(5.9)$ & 25 & -- & 23.0 \\
\hline $3 / 30$ & $26(5.9)$ & 25 & -- & 22.0 \\
\hline $3 / 31$ & $26(5.3)$ & 24 & - & 21.0 \\
\hline $4 / 1$ & $25(5.5)$ & 24 & 23.2 & -- \\
\hline $4 / 2$ & $23(5.0)$ & 23 & 21.3 & - \\
\hline $4 / 3$ & $20(4.0)$ & 22 & -- & 19.0 \\
\hline $4 / 4$ & $19(5.8)$ & 22 & -- & 16.0 \\
\hline $4 / 5$ & $16(5.0)$ & 21 & -- & 12.0 \\
\hline $4 / 6$ & $14(6.0)$ & 20 & 15.4 & 10.0 \\
\hline $4 / 7$ & $14(5.5)$ & 20 & 13.8 & -- \\
\hline $4 / 8$ & $14(5.5)$ & 19 & -- & -- \\
\hline $4 / 9$ & $14(6.2)$ & 19 & -- & 8.0 \\
\hline $4 / 10$ & $13(6.0)$ & 19 & -- & 7.0 \\
\hline $4 / 11$ & $10(5.2)$ & 16 & 9.1 & 5.0 \\
\hline $4 / 12$ & $9(4.5)$ & 16 & -- & 3.0 \\
\hline $4 / 13$ & $8(4.2)$ & 15 & -- & 2.0 \\
\hline $4 / 14$ & $8(4.1)$ & 14 & -- & 1.0 \\
\hline $4 / 15$ & $7(4.3)$ & 12 & -- & $\mathrm{T}$ \\
\hline $4 / 16$ & $6(1.8)$ & 11 & -- & $T$ \\
\hline $4 / 17$ & $6(1.9)$ & 11 & -- & $T$ \\
\hline $4 / 18$ & $4(1.1)$ & 9 & -- & $\mathrm{T}$ \\
\hline $4 / 19$ & $\mathrm{~T}(\mathrm{~T})$ & 8 & -- & $T$ \\
\hline $4 / 20$ & - & 7 & -- & $\mathrm{T}$ \\
\hline $4 / 21$ & -- & 6 & -- & $\mathrm{T}$ \\
\hline $4 / 22$ & -- & 3 & -- & $\mathrm{T}$ \\
\hline $4 / 23$ & -- & $\mathrm{T}$ & -- & $\mathrm{T}$ \\
\hline $4 / 24$ & - & $\mathrm{T}$ & -- & $\mathrm{T}$ \\
\hline $4 / 25$ & -- & $\mathrm{T}$ & -- & $\mathrm{T}$ \\
\hline $4 / 26$ & -- & $\mathrm{T}$ & -- & $\mathrm{T}$ \\
\hline $4 / 27$ & -- & $\mathrm{T}$ & -- & -- \\
\hline $4 / 28$ & -- & $\mathrm{T}$ & -- & -- \\
\hline
\end{tabular}




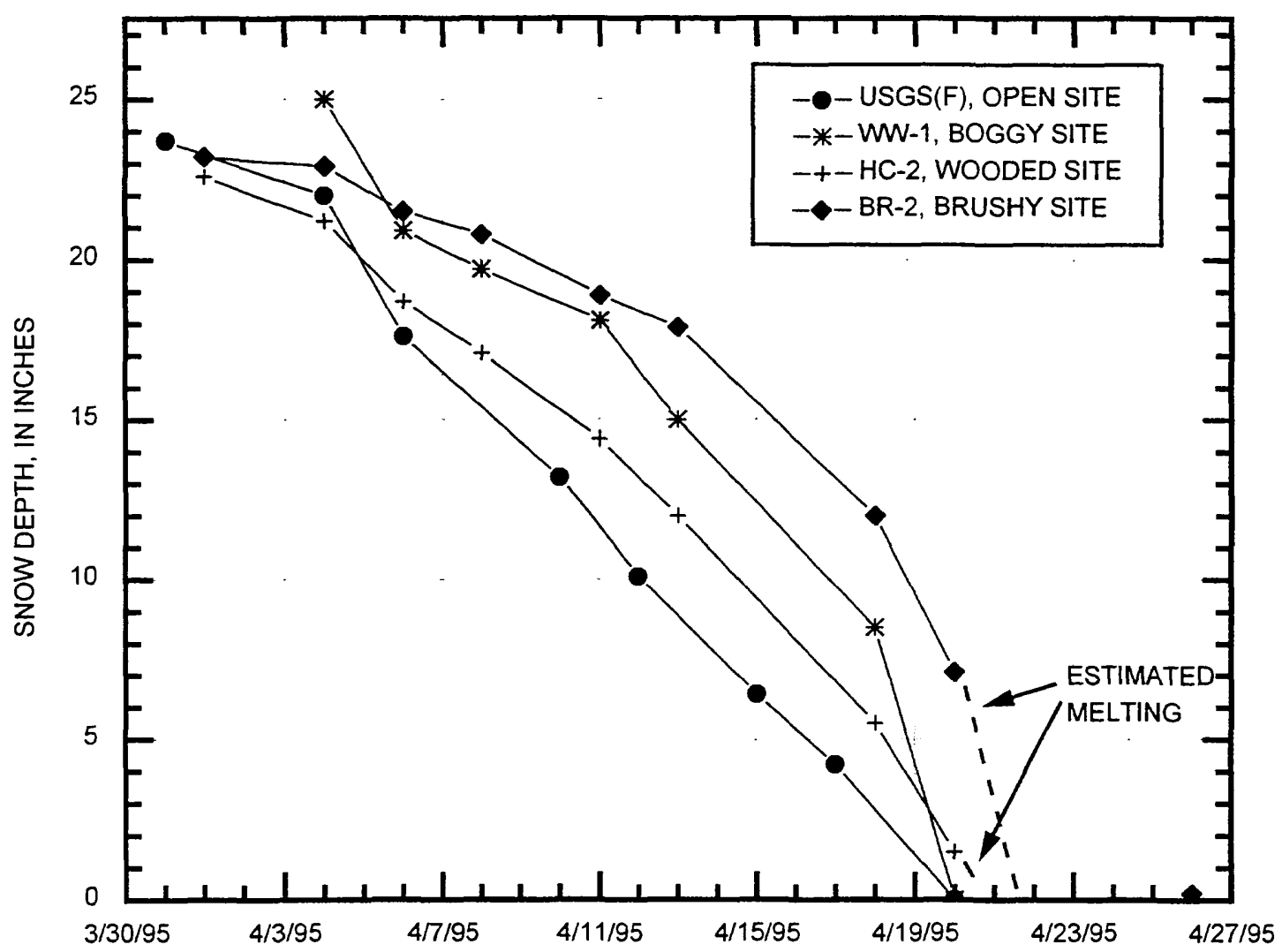

Figure 4. Snowpack depth change at open, boggy, wooded, and brushy sites.

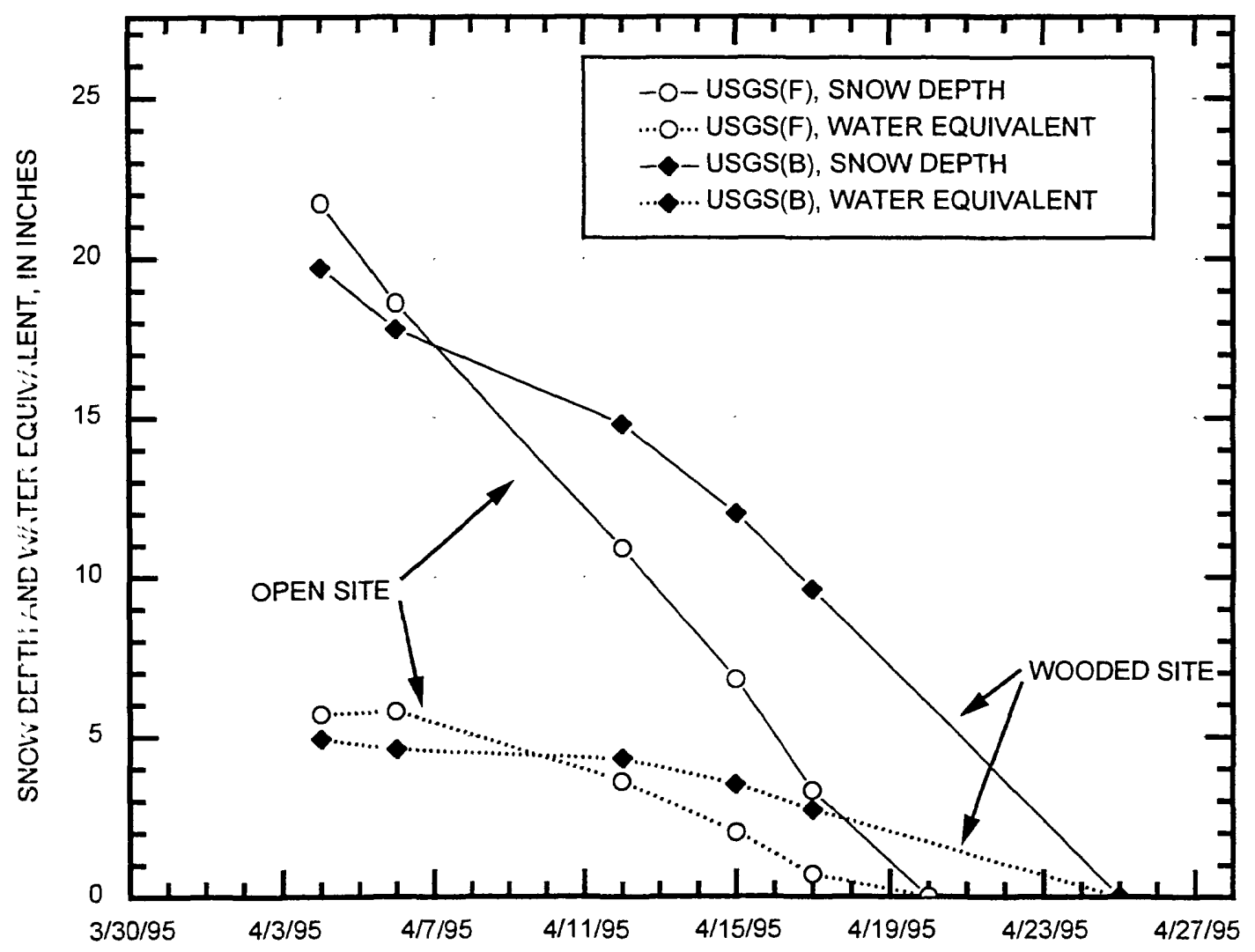

Figure 5. Snowpack depth and water-equivalent change at open and wooded sites. 
USGS(F) is an open site. Site USGS(B) is a wooded site. The two sites are located within about 330 feet of each other near the USGS Fairbanks field office. For the April 6 through April 12 period, snow depth decreased by 7.7 inches at the open site but decreased by only 3.0 inches at the wooded site. Similar results were recorded for water equivalents. At the open USGS(F) site, water equivalent decreased by 2.2 inches, while at the wooded USGS(B) site, water equivalent decreased by only 0.3 inch (fig. 5 ).

\section{SUMMARY}

The USGS, in cooperation with other government agencies, collected snow depths at 34 sites, and snow water-equivalent data at 13 of these sites, in the vicinity of Fairbanks, Alaska, during the spring of 1995. Measurements were made from the beginning of the snowmelt period (March 30) until snow had completely melted at all sites (April 26). Data collection sites were classified by vegetation cover as either open, boggy, wooded, or brushy. Snow depths and water equivalents were comparatively greater at open and boggy sites than at wooded or brushy sites; however, snowpack melting rates at the open and boggy sites were also significantly higher than at the wooded or brushy sites. The timing and amount of recharge from the land surface may affect the distribution of contaminants in unsaturated soils and their transport to the shallow water-table aquifer in the alluvial plain. This information may be used in future efforts to model the timing and distribution of aquifer recharge and to track possible distribution of contaminants in the ground- and surfacewater systems in the Fairbanks area, and, in particular, at four study areas with known or suspected subsurface contaminants.

\section{REFERENCES CITED}

Anderson, G.S., 1970, Hydrologic reconnaissance of the Tanana Basin, Central Alaska: U.S. Geological Survey Hydrologic Investigations Atlas HA-319, 4 sheets.

Benson, C.S. and Trabant, D.C., 1973, Field measurements on the flux of water vapor through dry snow in The role of snow and ice in hydrology: Banff Symposium, 1972, UNESCO-WMO-IASH Publication 107, v. 1, Proceedings, p. 291-298.

Friedman, Irving, Benson, Carl, and Gleason, Jim, 1991, Isotopic changes during snow metamorphism in Taylor, H.P., Jr., O'Neil, J.R., and Kaplan, I.R., Stable isotope geochemistry: A tribute to Samuel Epstein: The Geochemical Society, Special Publication no. 3, p. 211-221.

National Oceanic and Atmospheric Administration, 1978, Local climatological data, annual summary with comparative data, 1978, Fairbanks, Alaska: Asheville, N.C., National Oceanic and Atmospheric Administration, 4 p.

1994, Climatological data, Alaska: Asheville, N.C., National Oceanic and Atmospheric Administration, v. 80, no. 13.

Sturm, M., 1989, The role of convection in heat and mass transport in the subarctic snow cover: Fairbanks, Alaska, University of Alaska Fairbanks, Ph.D. dissertation, 189 p.

1991, The role of thermal convection in heat and mass transport in the subarctic snow cover: U.S. Army Cold Regions Research and Engineering Laboratory Report 91-19, 84 p.

Trabant, D., 1970, Diagenesis of the seasonal snow cover of interior Alaska: Fairbanks, Alaska, University of Alaska Fairbanks, M.S. thesis, 44 p. 
Traba.t, D.C., and Benson, C.S., 1972, Field experiments on the development of depth hoar in Doe, B.R., and Smith, D.K., eds., Studies in mineralogy and Precambrian geology: Geological Society of America Memoir 135, p. 309322.

U.S. Soil Conservation Service, 1983, Summary of snow survey measurements for Alaska, 1951-1982: U.S. Departx.ent of Agriculture, Soil Conservation Service, and Alaska Soil Conservation District, 209 p. 


\section{APPENDIX A}

Measured snow depths 


\begin{tabular}{|c|c|c|c|}
\hline & 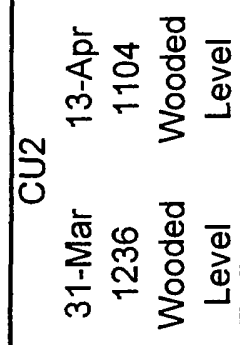 & 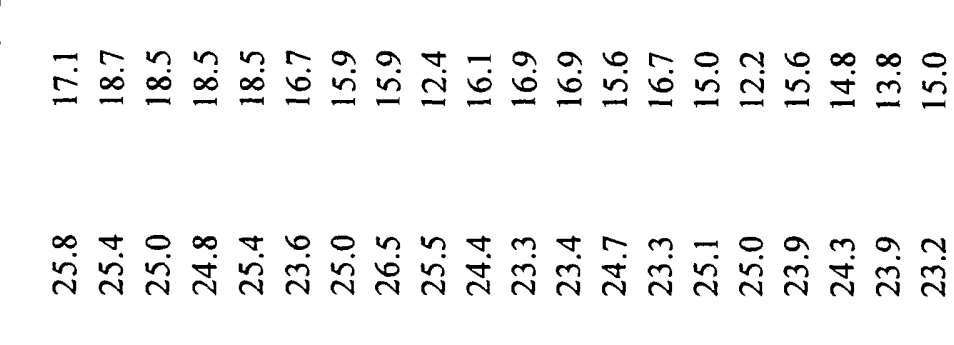 & $\underset{10}{0}$ \\
\hline 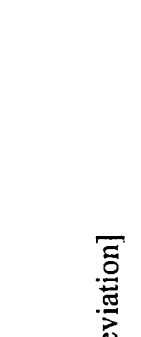 & 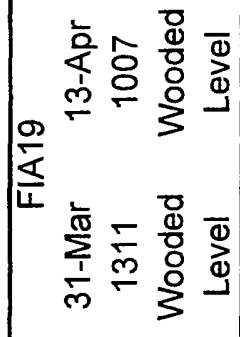 & 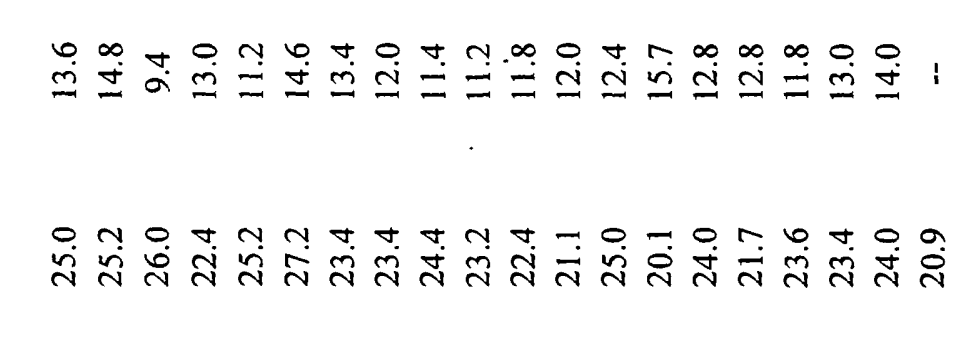 & 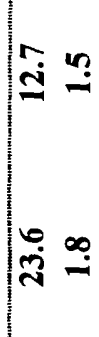 \\
\hline 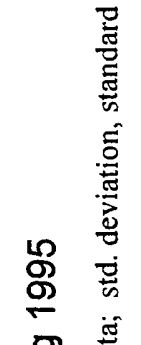 & 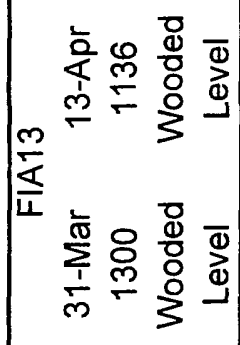 & 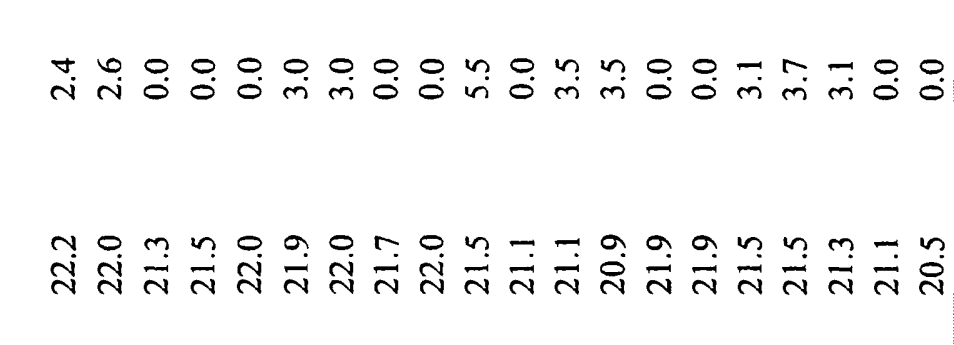 & 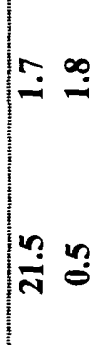 \\
\hline 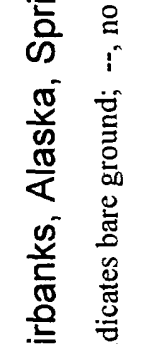 & 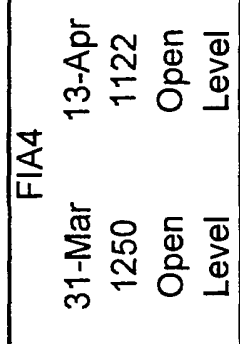 & 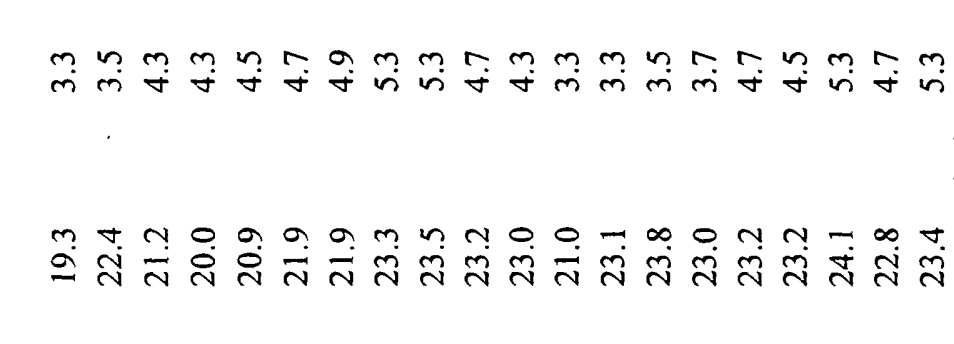 & $\underset{\mathrm{A}}{\mathbb{\Delta}}=$ \\
\hline 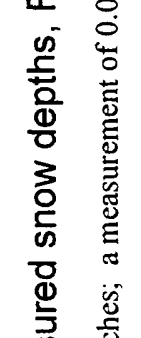 & 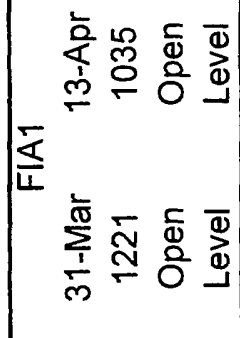 & 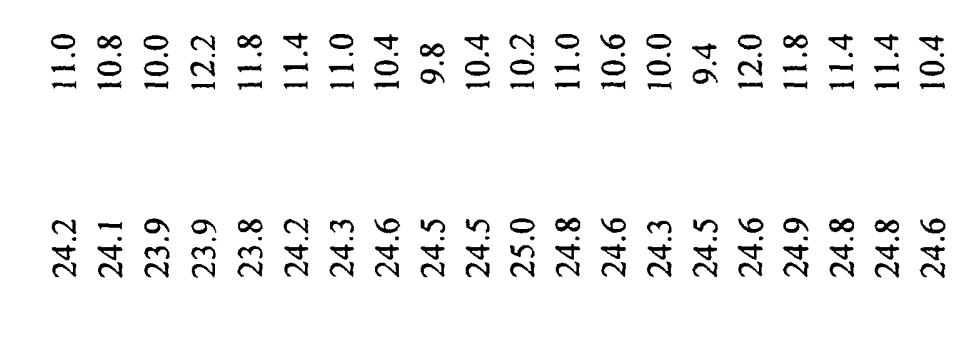 & $\mid \begin{array}{l}\stackrel{\infty}{\ominus} \stackrel{\infty}{0} \\
\vec{\sim} \dot{\sim}\end{array}$ \\
\hline 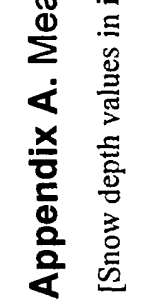 & 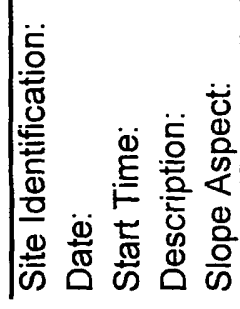 & 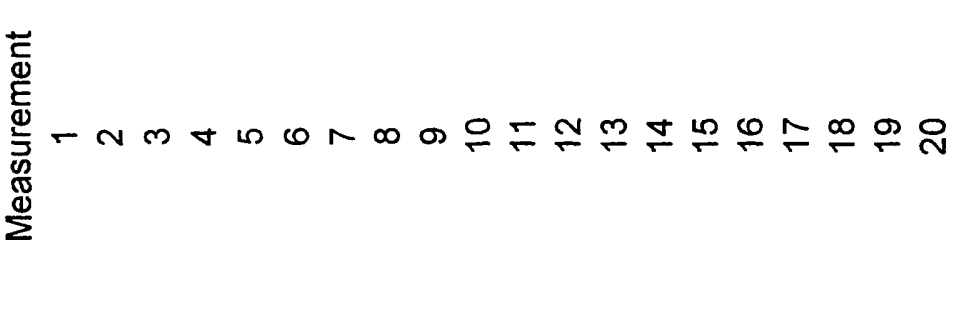 & 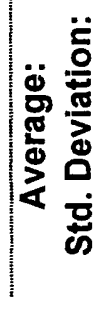 \\
\hline
\end{tabular}




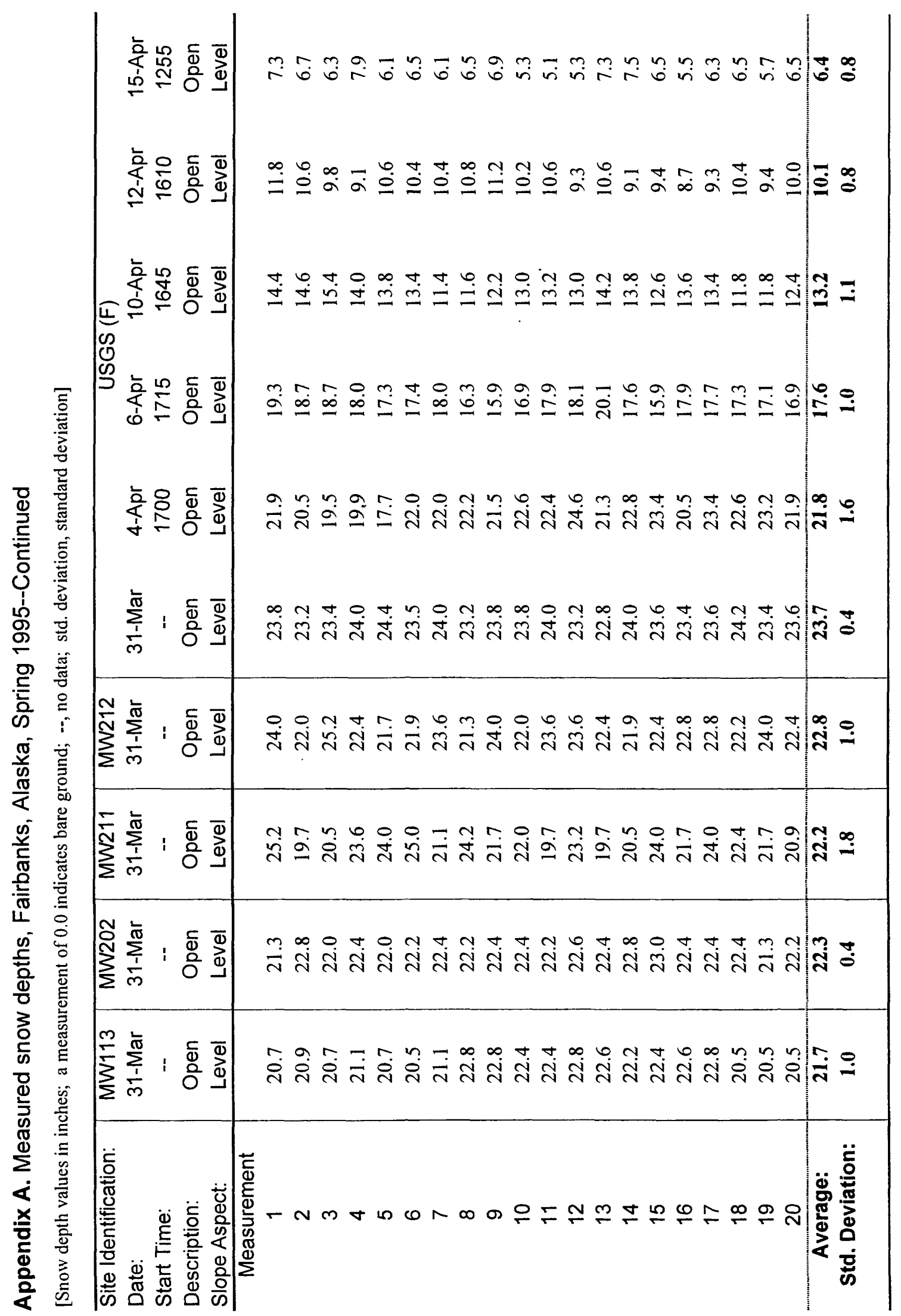




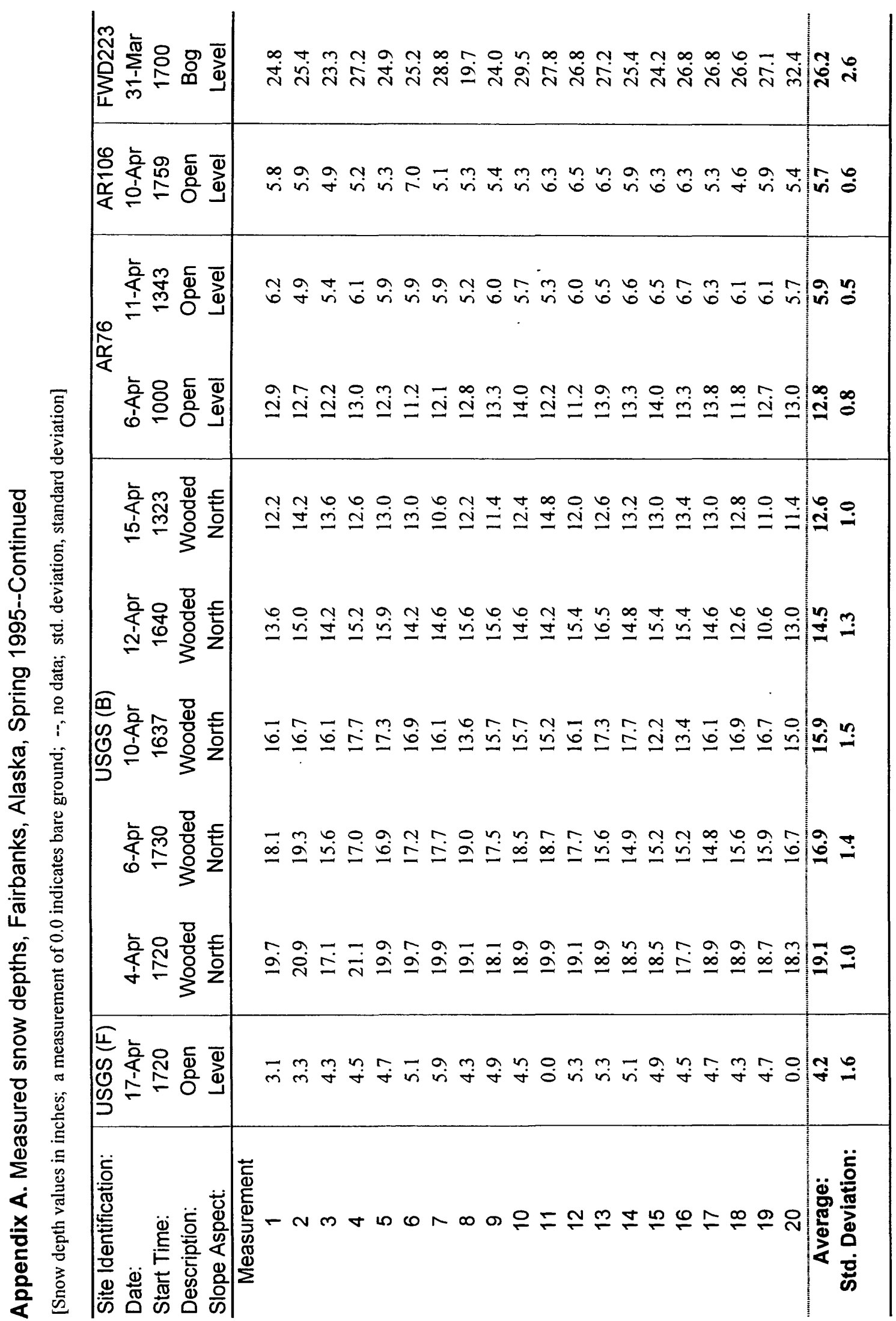




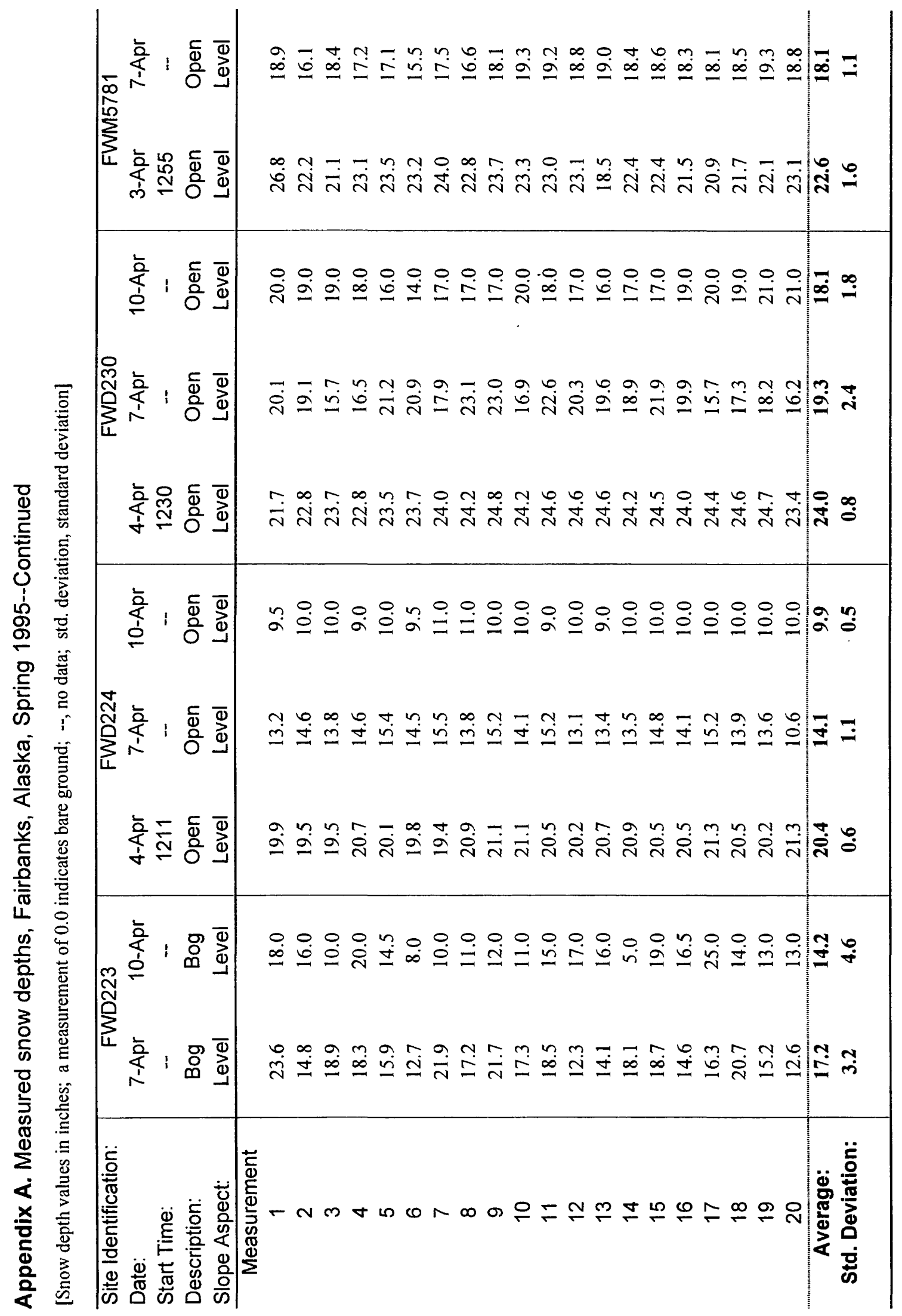




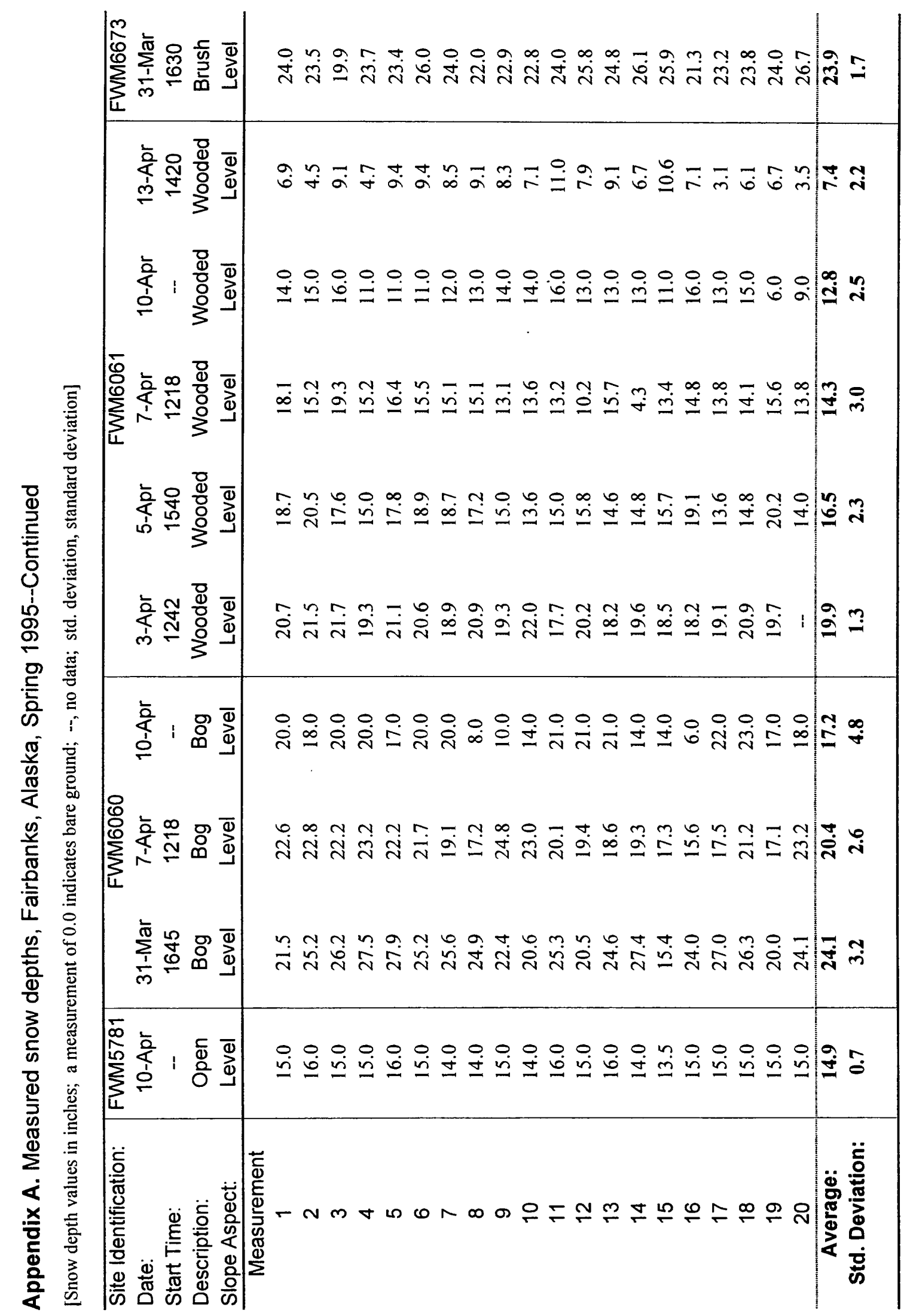




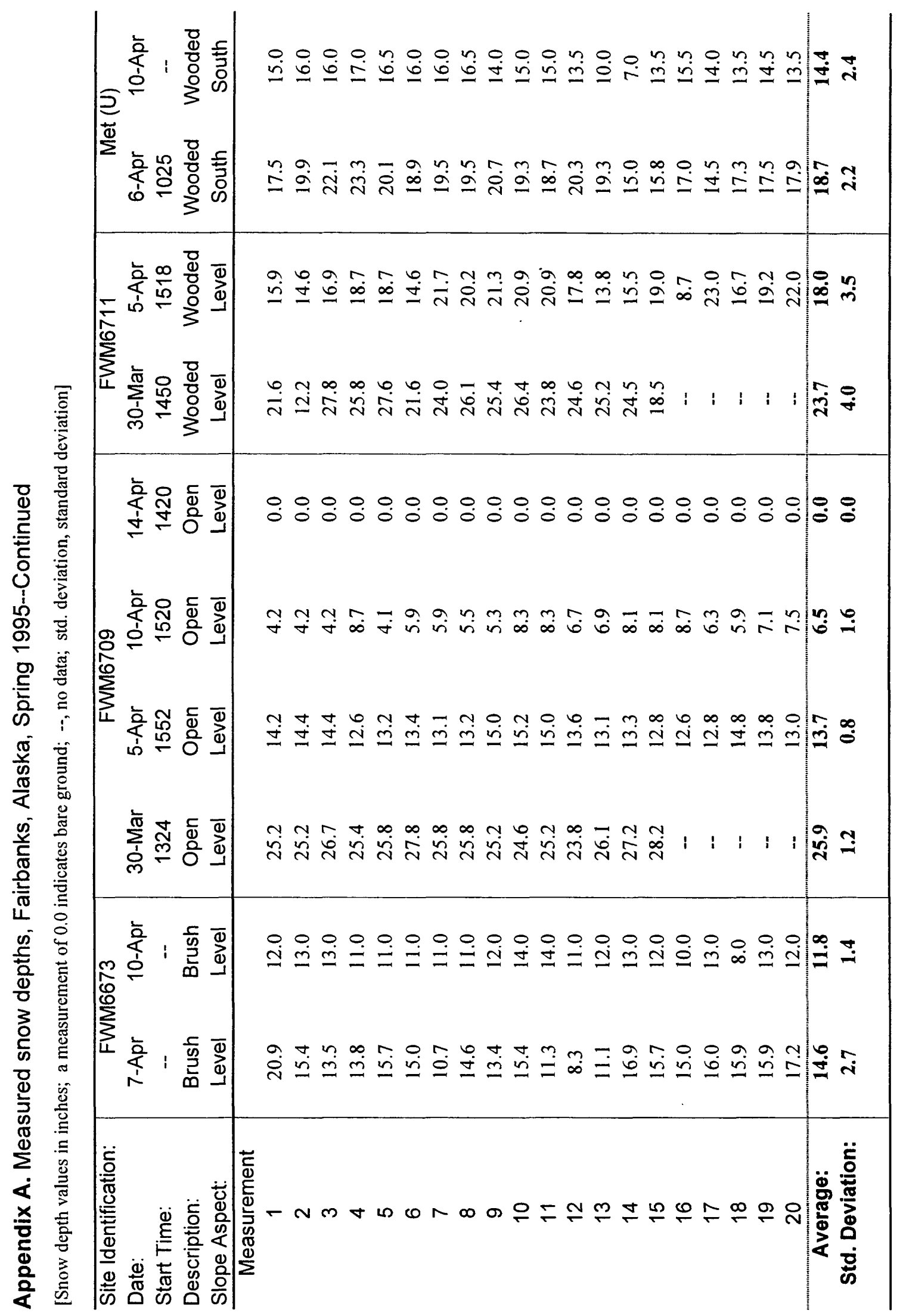




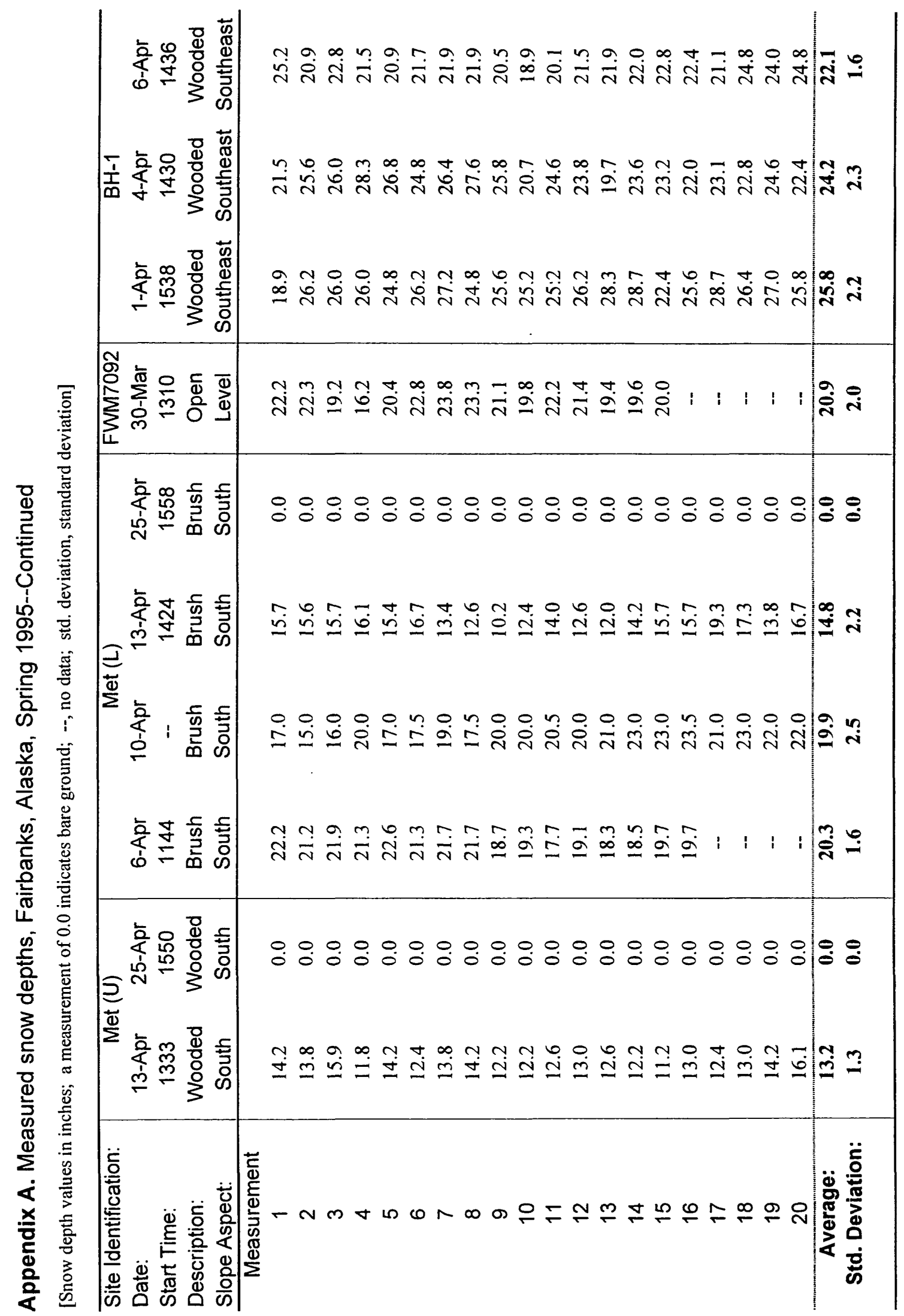




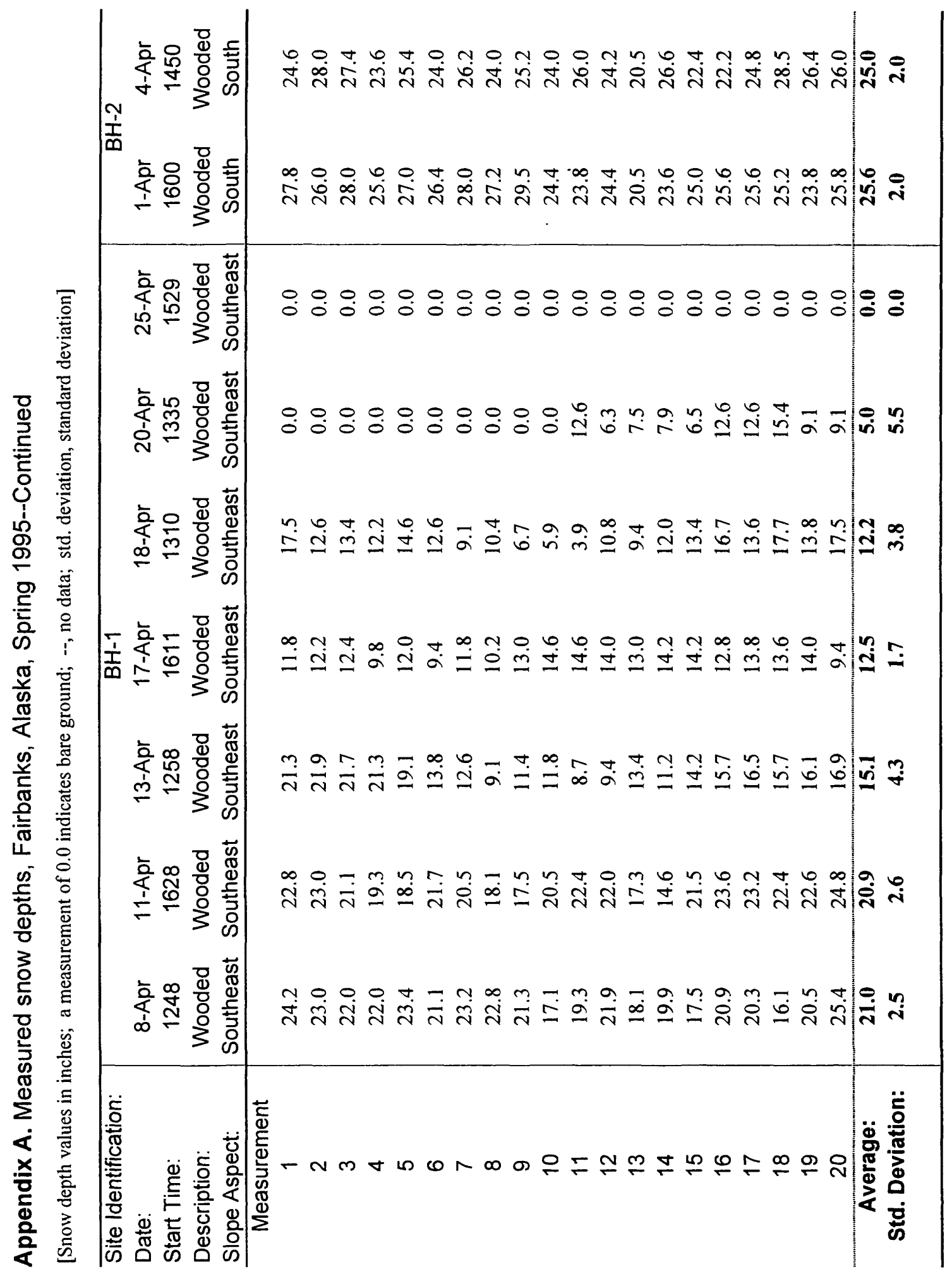




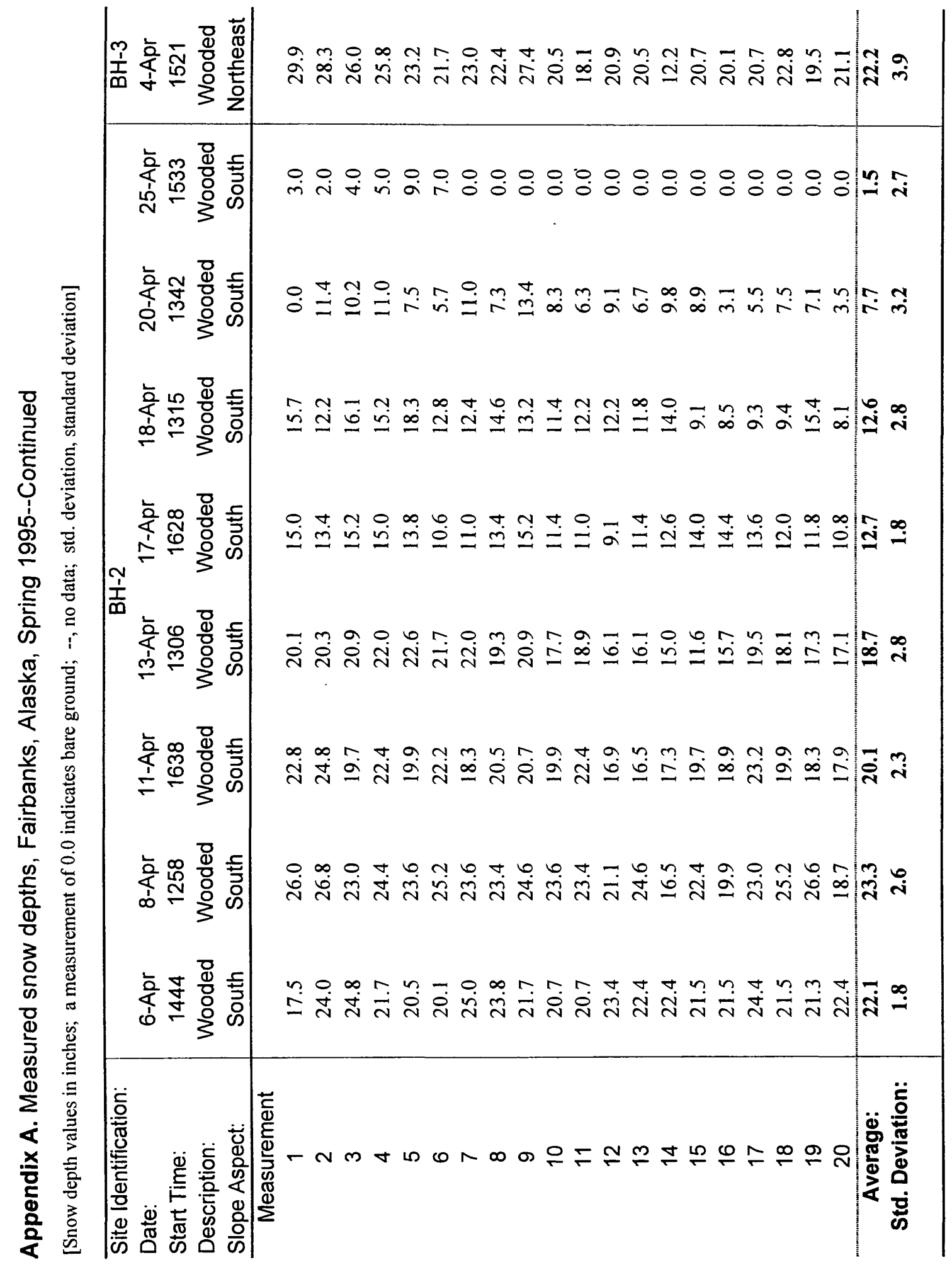




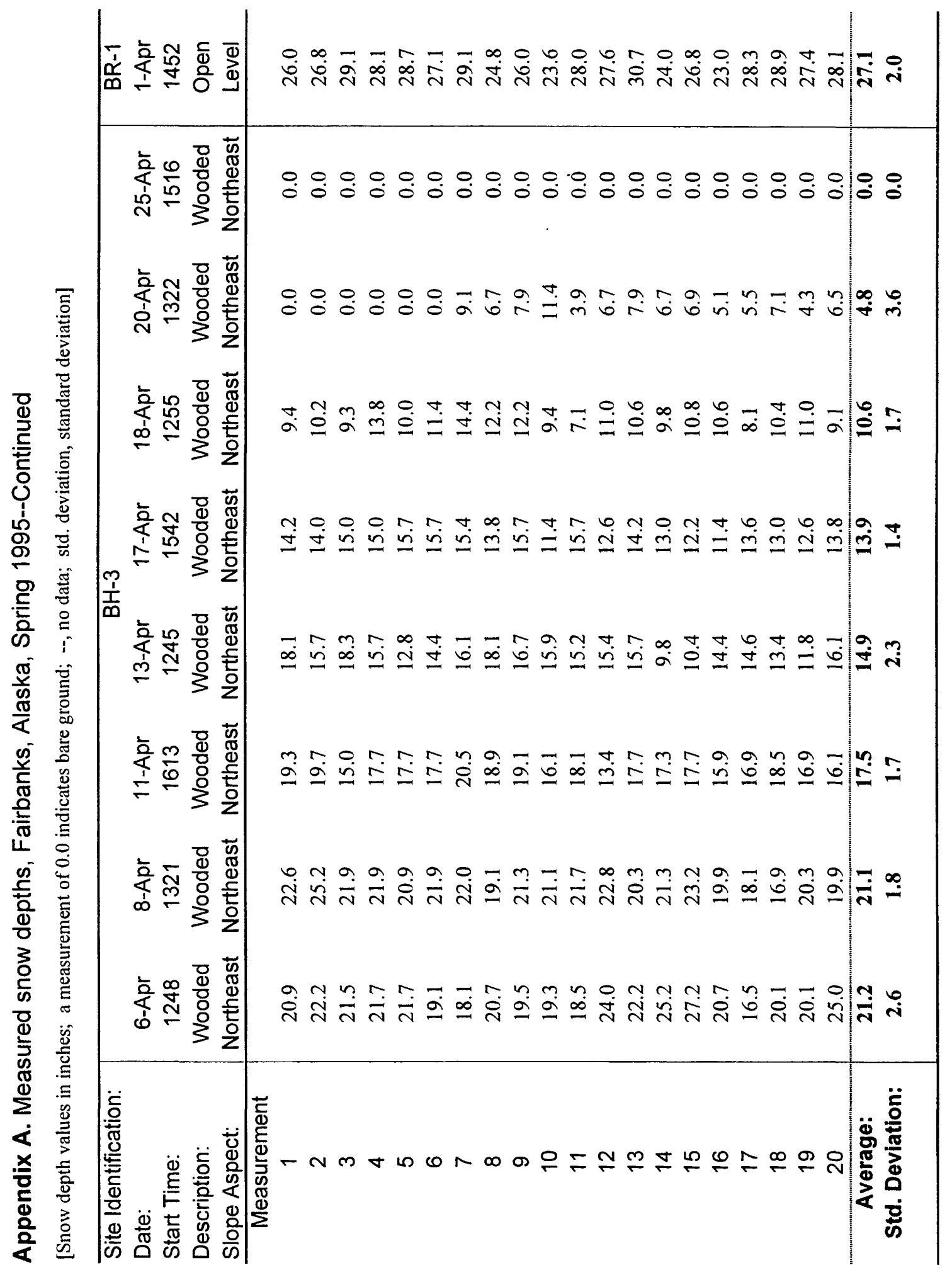




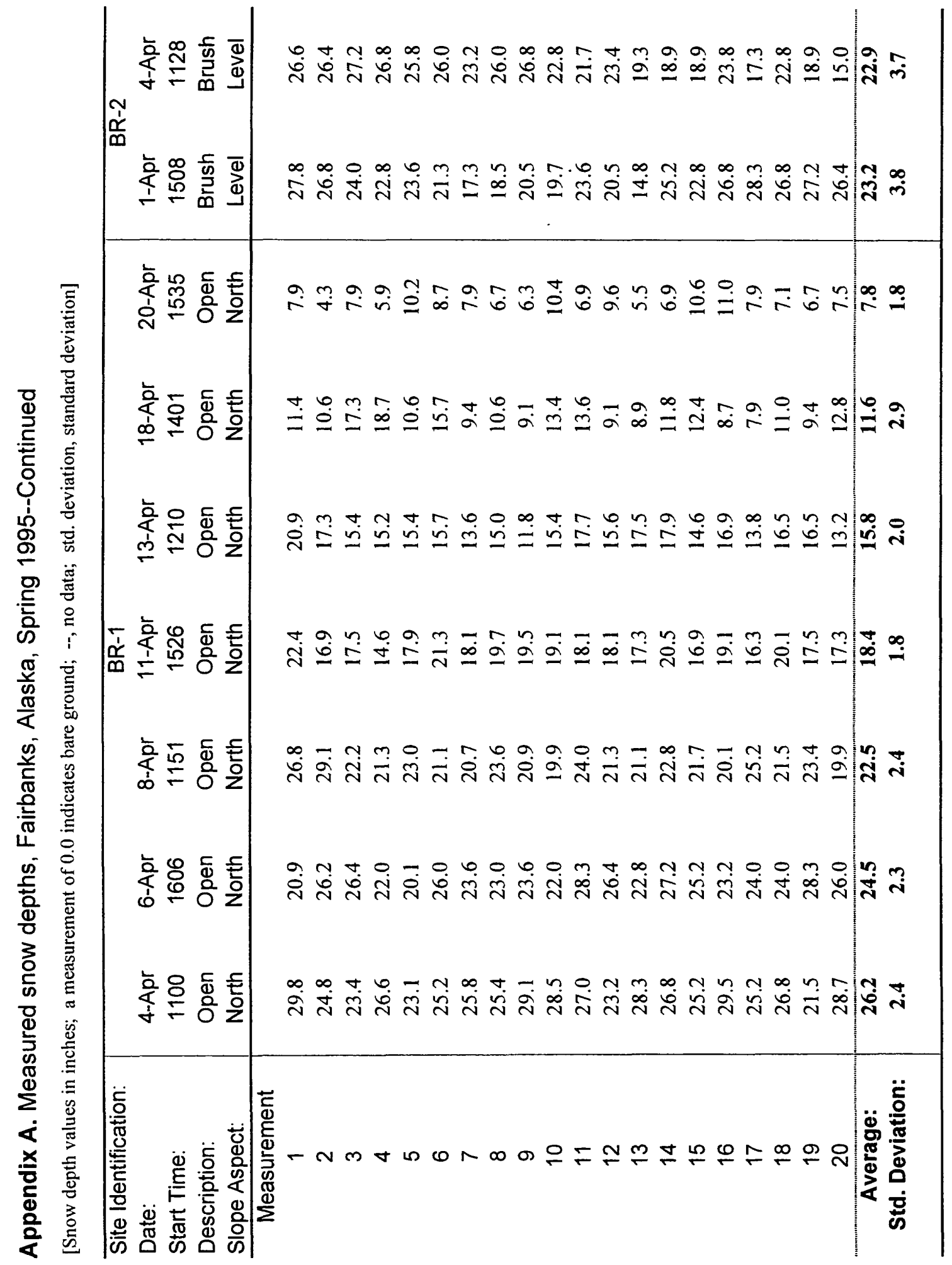




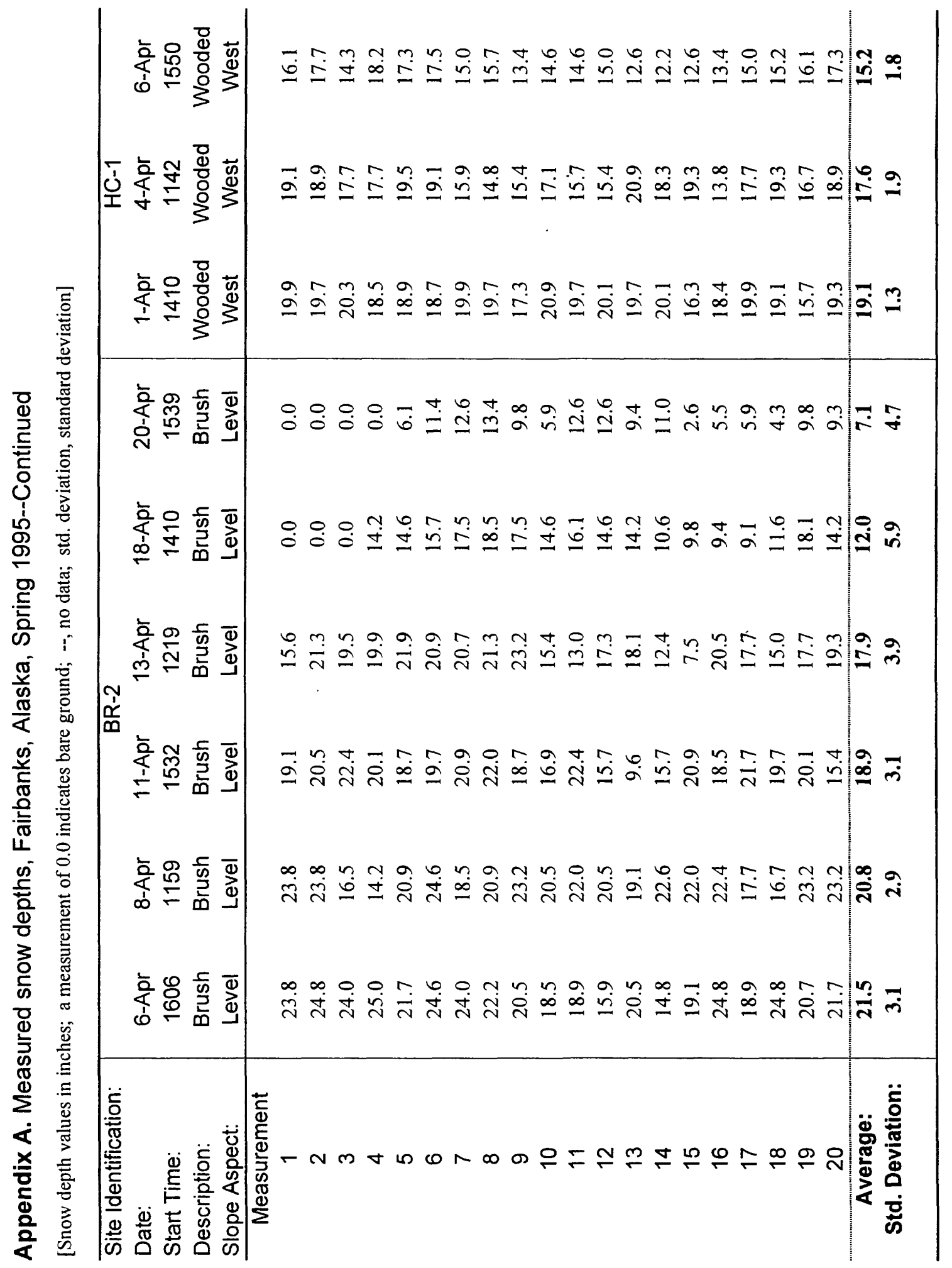




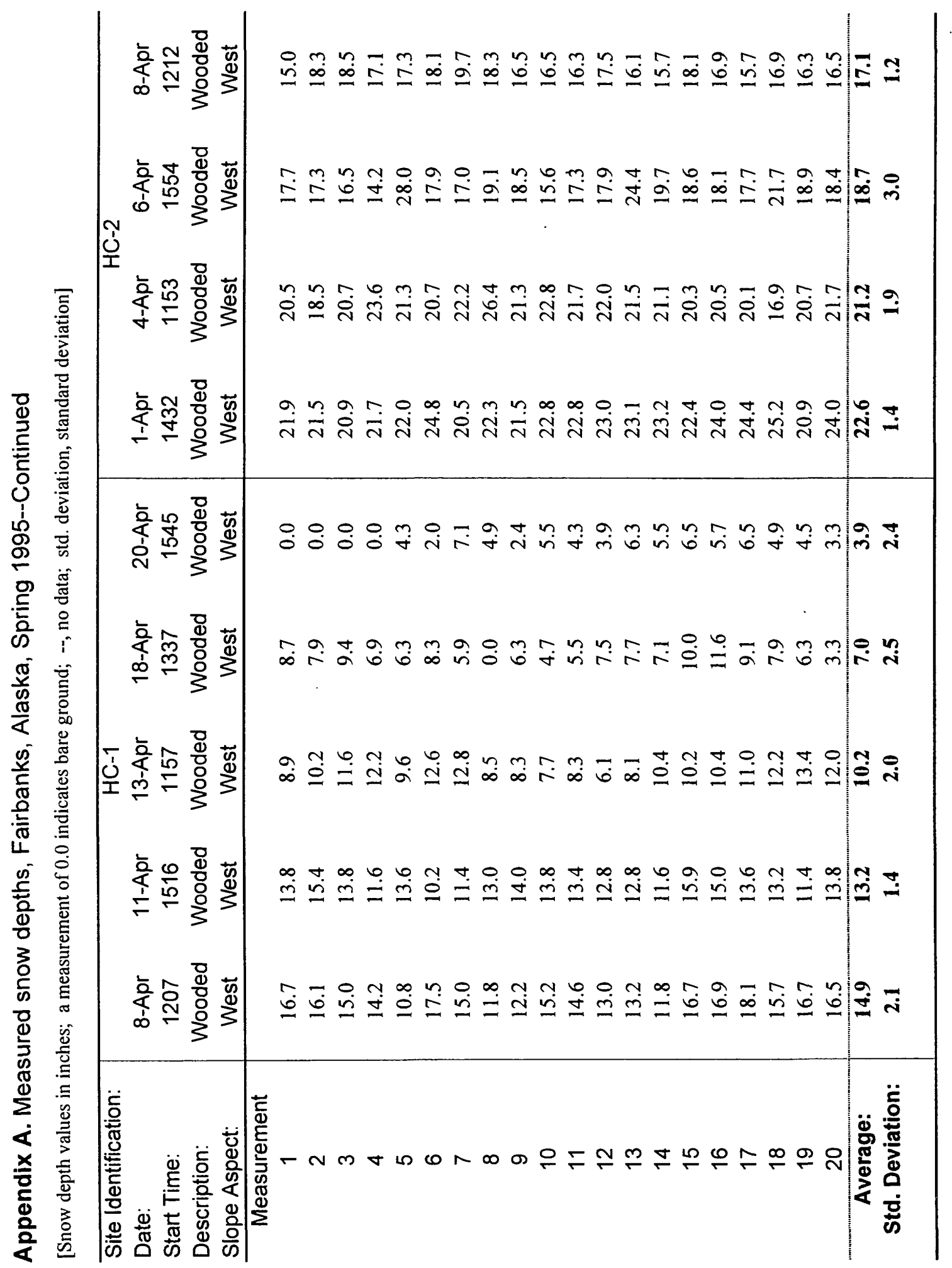




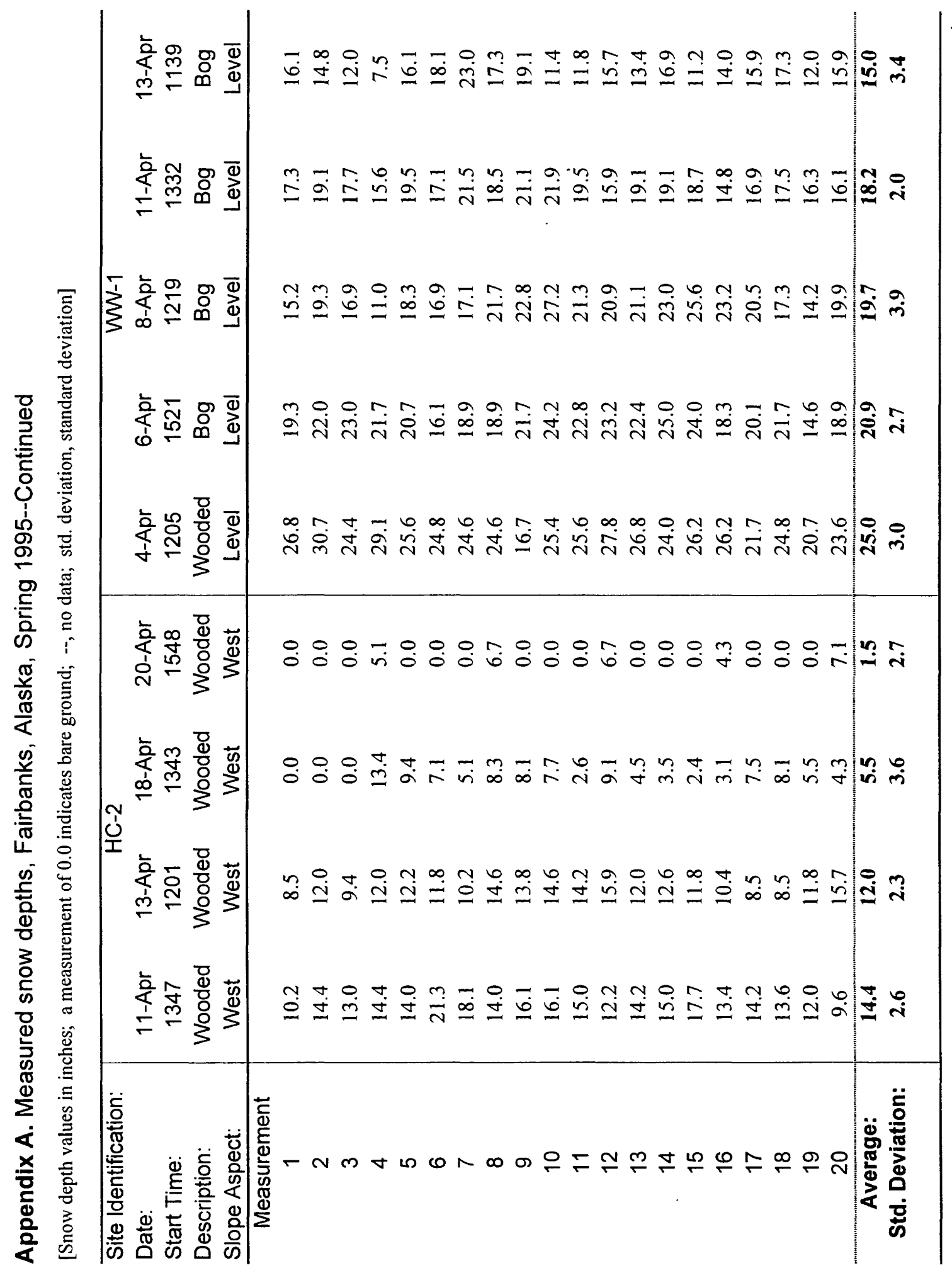




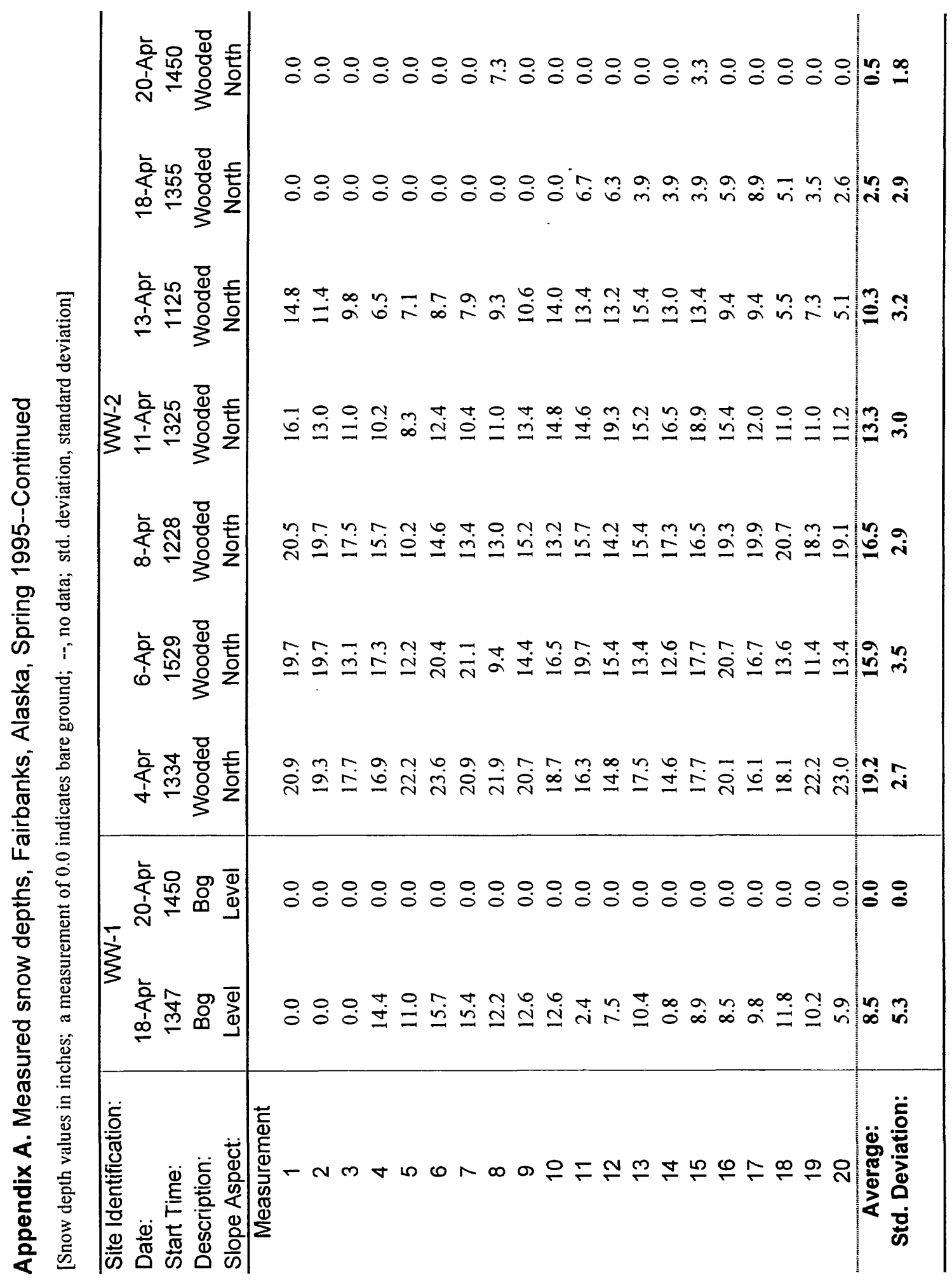


APPENDIX B

Measured snow depths and water equivalents 
Appendix B. Measured snow depths and water equivalents for selected sites, Fairbanks, Alaska, Spring 1995

[Snow depth and water equivalent $\left(\mathrm{H}_{2} \mathrm{O}\right.$ Eq.) values in inches; a measurement of 0.0 indicates bare ground; -, no data; std. deviation, standard deviation]

\begin{tabular}{|c|c|c|c|c|c|c|c|c|}
\hline Site Identification: & \multicolumn{8}{|c|}{ USGS (F) } \\
\hline Date: & \multicolumn{2}{|c|}{ 4-Apr } & \multicolumn{2}{|c|}{ 6-Apr } & \multicolumn{2}{|c|}{ 12-Apr } & \multicolumn{2}{|c|}{ 15-Apr } \\
\hline Start Time: & \multicolumn{2}{|c|}{1700} & \multicolumn{2}{|c|}{1730} & \multicolumn{2}{|c|}{1610} & \multicolumn{2}{|c|}{1255} \\
\hline Description: & \multicolumn{2}{|c|}{ Open } & \multicolumn{2}{|c|}{ Open } & \multicolumn{2}{|c|}{ Open } & \multicolumn{2}{|c|}{ Open } \\
\hline Slope Aspect: & \multicolumn{2}{|c|}{ Level } & \multicolumn{2}{|c|}{ Level } & \multicolumn{2}{|c|}{ Level } & \multicolumn{2}{|c|}{ Level } \\
\hline Measurement & Depth & $\mathrm{H}_{2} \mathrm{O} \mathrm{Eq}$. & Depth & $\mathrm{H}_{2} \mathrm{O}$ Eq. & $\overline{\text { Depth }}$ & $\mathrm{H}_{2} \mathrm{O} \mathrm{Eq}$. & Depth & $\mathrm{H}_{2} \mathrm{O} \mathrm{Eq}$. \\
\hline 1 & 22.0 & 5.3 & 20.0 & 5.9 & 10.0 & 3.5 & 6.0 & 1.5 \\
\hline 2 & 16.0 & 5.0 & 19.0 & 6.1 & 13.0 & 4.0 & 7.0 & 2.1 \\
\hline 3 & 20.0 & 6.4 & 19.0 & 5.8 & 10.0 & 3.4 & 7.0 & 2.3 \\
\hline 4 & 23.0 & 5.6 & 19.0 & 6.0 & 11.0 & 3.9 & 7.0 & 1.8 \\
\hline 5 & 22.0 & 5.6 & 17.0 & 5.7 & 10.0 & 3.5 & 6.0 & 2.0 \\
\hline 6 & 21.0 & 5.9 & 17.0 & 5.5 & 10.0 & 3.0 & 6.0 & 1.6 \\
\hline 7 & 24.0 & 5.9 & 18.0 & 5.5 & 13.0 & 4.2 & 8.0 & 2.1 \\
\hline 8 & 23.0 & 5.9 & 19.0 & 5.8 & 10.0 & 3.2 & 7.0 & 2.2 \\
\hline 9 & 23.0 & 5.5 & 18.0 & 5.9 & 11.0 & 3.8 & 7.0 & 2.3 \\
\hline 10 & 23.0 & 5.7 & 20.0 & 6.1 & 11.0 & 3.6 & 7.0 & 2.3 \\
\hline Average: & 21.7 & 5.7 & 18.6 & 5.8 & 10.9 & 3.6 & 6.8 & 2.0 \\
\hline Std. Deviation: & 2.3 & 0.4 & 1.1 & 0.2 & 1.2 & 0.4 & 0.6 & 0.3 \\
\hline
\end{tabular}

\begin{tabular}{|c|c|c|c|c|c|c|c|c|}
\hline \multirow{5}{*}{$\begin{array}{l}\text { Site ldentitication: } \\
\text { Date: } \\
\text { Start Time: } \\
\text { Description: } \\
\text { Slope Aspect: }\end{array}$} & \multirow{2}{*}{\multicolumn{2}{|c|}{$\begin{array}{c}\text { USGS (F) } \\
\text { 17-Apr }\end{array}$}} & \multicolumn{6}{|c|}{ USGS (B) } \\
\hline & & & \multirow{4}{*}{\multicolumn{2}{|c|}{$\begin{array}{c}\text { 4-Apr } \\
1720 \\
\text { Wooded } \\
\text { North }\end{array}$}} & \multirow{4}{*}{\multicolumn{2}{|c|}{$\begin{array}{c}\text { 6-Apr } \\
1730 \\
\text { Wooded } \\
\text { North }\end{array}$}} & \multirow{4}{*}{\multicolumn{2}{|c|}{$\begin{array}{c}\text { 12-Apr } \\
1610 \\
\text { Wooded } \\
\text { North }\end{array}$}} \\
\hline & \multirow{3}{*}{\multicolumn{2}{|c|}{$\begin{array}{l}1720 \\
\text { Open } \\
\text { Level }\end{array}$}} & & & & & & \\
\hline & & & & & & & & \\
\hline & & & & & & & & \\
\hline Measurement & Depth & $\mathrm{H}_{2} \mathrm{O} \mathrm{Eq}$ & Depth & $\mathrm{H}_{2} \mathrm{O} \mathrm{Eq}$. & Depth & $\mathrm{H}_{2} \mathrm{O} \mathrm{Eq}$. & Depth & $\mathrm{H}_{2} \mathrm{O} \mathrm{Eq}$. \\
\hline 1 & 4.0 & 0.9 & 20.0 & 5.0 & 19.0 & 5.1 & 14.0 & 4.0 \\
\hline 2 & 4.0 & 1.0 & 20.0 & 4.7 & 19.0 & 4.9 & 14.0 & 4.0 \\
\hline 3 & 3.0 & 0.8 & 18.0 & 4.6 & 18.5 & 4.3 & 16.0 & 4.3 \\
\hline 4 & 3.0 & 0.5 & 20.0 & 4.9 & 17.0 & 4.5 & 16.0 & 4.4 \\
\hline 5 & 4.0 & 1.0 & 20.0 & 5.1 & 17.0 & 5.0 & 16.0 & 5.1 \\
\hline 6 & 5.0 & 0.9 & 19.0 & 4.9 & 18.5 & 5.0 & 16.0 & 4.3 \\
\hline 7 & 0.0 & 0.0 & 20.0 & 5.3 & 15.0 & 3.9 & 16.0 & 4.7 \\
\hline 8 & 3.0 & 0.9 & 21.0 & 5.0 & 18.0 & 4.7 & 14.0 & 4.4 \\
\hline 9 & 4.0 & 0.5 & 20.0 & 5.3 & 17.0 & 4.5 & 16.0 & 4.5 \\
\hline 10 & 3.0 & 0.6 & 19.0 & 4.5 & 18.5 & 4.6 & 10.0 & 2.8 \\
\hline Average: & 3.3 & 0.7 & 19.7 & 4.9 & 17.8 & 4.6 & 14.8 & 4.3 \\
\hline Std. Deviation: & 1.3 & 0.3 & 0.8 & 0.3 & 1.3 & 0.4 & 1.9 & 0.6 \\
\hline
\end{tabular}


Appendix B. Measured snow depths and water equivalents for selected sites, Fairbanks, Alaska, Spring 1995--Continued

[Snow depth and water equivalent $\left(\mathrm{H}_{2} \mathrm{O}\right.$ Eq.) values in inches; a measurement of 0.0 indicates bare ground; --, no data; std. deviation, standard deviation]

\begin{tabular}{|c|c|c|c|c|c|c|c|c|}
\hline Site Identification: & \multicolumn{4}{|c|}{ USGS (B) } & \multicolumn{4}{|c|}{ Met $(\mathrm{U})$} \\
\hline Date: & \multicolumn{2}{|c|}{ 15-Apr } & \multicolumn{2}{|c|}{ 17-Apr } & \multicolumn{2}{|c|}{ 6-Apr } & \multicolumn{2}{|c|}{ 13-Apr } \\
\hline Start Time: & \multicolumn{2}{|c|}{1323} & \multicolumn{2}{|c|}{1701} & \multicolumn{2}{|c|}{1025} & \multicolumn{2}{|c|}{1333} \\
\hline Description: & \multicolumn{2}{|c|}{ Wooded } & \multirow{2}{*}{\multicolumn{2}{|c|}{$\begin{array}{l}\text { Wooded } \\
\text { North }\end{array}$}} & \multirow{2}{*}{\multicolumn{2}{|c|}{$\begin{array}{l}\text { Wooded } \\
\text { South }\end{array}$}} & \multirow{2}{*}{\multicolumn{2}{|c|}{$\begin{array}{l}\text { Wooded } \\
\text { South }\end{array}$}} \\
\hline Slope Aspect: & & & & & & & & \\
\hline Measurement & Depth & $\mathrm{H}_{2} \mathrm{O} \mathrm{Eq}$. & Depth & $\mathrm{H}_{2} \mathrm{O} \mathrm{Eq}$. & Depth & $\mathrm{H}_{2} \mathrm{O} \mathrm{Eq}$. & Depth & $\mathrm{H}_{2} \mathrm{O} \mathrm{Eq}$. \\
\hline 1 & 12.0 & 3.6 & 9.0 & 2.6 & 17.0 & 5.4 & 12.0 & 3.5 \\
\hline 2 & 11.0 & 3.6 & 9.0 & 2.6 & 19.0 & 6.8 & 12.0 & 3.7 \\
\hline 3 & 11.0 & 3.3 & 11.0 & 3.0 & 17.0 & 5.1 & 12.0 & 4.0 \\
\hline 4 & 14.0 & 3.9 & 9.0 & 2.4 & 18.0 & 5.3 & 14.0 & 5.1 \\
\hline 5 & 13.0 & 3.8 & 10.0 & 2.8 & 20.0 & 4.9 & 14.0 & 4.4 \\
\hline 6 & 12.0 & 3.2 & 11.0 & 3.1 & 18.0 & 4.9 & 11.0 & 3.6 \\
\hline 7 & 13.0 & 3.9 & 10.0 & 2.8 & 19.0 & 5.5 & 12.0 & 3.7 \\
\hline 8 & 13.0 & 4.2 & 11.0 & 3.5 & 20.0 & 5.6 & 14.0 & 4.5 \\
\hline 9 & 13.0 & 3.7 & 7.0 & 1.8 & 18.0 & 3.6 & 11.0 & 3.6 \\
\hline 10 & 8.0 & 2.4 & 9.0 & 2.5 & 17.0 & 5.3 & 14.0 & 4.5 \\
\hline Average: & 12.0 & 3.6 & 9.6 & 2.7 & $\overline{18.3}$ & 5.2 & 12.6 & 4.1 \\
\hline Std. Deviation: & 1.7 & 0.5 & 1.3 & 0.5 & 1.2 & 0.8 & 1.3 & 0.5 \\
\hline
\end{tabular}

\begin{tabular}{|c|c|c|c|c|c|c|c|c|}
\hline Site Identification: & \multirow{2}{*}{\multicolumn{2}{|c|}{$\begin{array}{c}\text { Met (U) } \\
\text { 18-Apr }\end{array}$}} & \multicolumn{6}{|c|}{ Met $(L)$} \\
\hline Date: & & & & & & & & \\
\hline Start Time: & & & & & & & & \\
\hline Description: & & ded & & & & & & \\
\hline Slope Aspect: & & & & & & & & \\
\hline Measurement & Depth & $\mathrm{H}_{2} \mathrm{O} \mathrm{Eq}$. & Depth & $\mathrm{H}_{2} \mathrm{O}$ Eq. & Depth & $\mathrm{H}_{2} \mathrm{O} \mathrm{Eq}$. & Depth & $\mathrm{H}_{2} \mathrm{O} \mathrm{Eq}$. \\
\hline 1 & 10.0 & 3.2 & 23.0 & 5.6 & 16.0 & 5.2 & 9.0 & 3.0 \\
\hline 2 & 8.0 & 2.5 & 24.0 & 6.2 & 15.0 & 4.9 & 0.0 & 0.0 \\
\hline 3 & 8.0 & 2.8 & 22.0 & 3.7 & 15.0 & 4.6 & 9.0 & 2.6 \\
\hline 4 & 8.0 & 2.5 & 22.0 & 4.0 & 15.0 & 4.2 & 8.0 & 2.7 \\
\hline 5 & 7.0 & 2.6 & 22.0 & 2.4 & 10.0 & 3.1 & 0.0 & 0.0 \\
\hline 6 & 6.0 & 2.3 & 23.0 & 3.9 & 16.0 & 5.4 & 0.0 & 0.0 \\
\hline 7 & 8.0 & 2.6 & 19.0 & 3.5 & 15.0 & 4.0 & 7.0 & 2.5 \\
\hline 8 & 8.0 & 2.6 & 21.0 & 2.6 & 17.0 & 5.3 & 0.0 & 0.0 \\
\hline 9 & 8.0 & 2.5 & 22.0 & 5.6 & 15.0 & 5.1 & 8.0 & 2.4 \\
\hline 10 & 6.0 & 2.4 & 21.0 & 3.5 & 13.0 & 4.2 & 0.0 & 0.0 \\
\hline Average: & 7.7 & 2.6 & 21.9 & 4.1 & 14.7 & 4.6 & 4.1 & 1.3 \\
\hline Std. Deviation: & 1.2 & 0.2 & 1.4 & 1.3 & 1.9 & 0.7 & 4.4 & 1.4 \\
\hline
\end{tabular}


Appendix B. Measured snow depths and water equivalents for selected sites, Fairbanks, Alaska, Spring 1995--Continued

[Snow depth and water equivalent $\left(\mathrm{H}_{2} \mathrm{O}\right.$ Eq.) values in inches; a measurement of 0.0 indicates bare ground; -, no data; std. deviation, standard deviation]

\begin{tabular}{|c|c|c|c|c|c|c|c|c|}
\hline Site Identification: & \multicolumn{8}{|c|}{$\overline{\mathrm{BH}-1}$} \\
\hline Date: & \multicolumn{2}{|c|}{ 1-Apr } & \multicolumn{2}{|c|}{ 4-Apr } & \multicolumn{2}{|c|}{ 10-Apr } & \multicolumn{2}{|c|}{ 17-Apr } \\
\hline Start Time: & \multicolumn{2}{|c|}{1538} & \multicolumn{2}{|c|}{1430} & \multicolumn{2}{|c|}{-} & \multicolumn{2}{|c|}{1611} \\
\hline Description: & \multicolumn{2}{|c|}{ Brush } & \multicolumn{2}{|c|}{ Brush } & \multicolumn{2}{|c|}{ Brush } & \multicolumn{2}{|c|}{ Brush } \\
\hline Slope Aspect: & & & & & & & & \\
\hline Measurement & Depth & $\mathrm{H}_{2} \mathrm{O} \mathrm{Eq}$. & Depth & $\mathrm{H}_{2} \mathrm{O} \mathrm{Eq}$. & Depth & $\mathrm{H}_{2} \mathrm{O} \mathrm{Eq}$. & Depth & $\mathrm{H}_{2} \mathrm{O} \mathrm{Eq}$. \\
\hline 1 & 25.0 & 4.6 & 25.0 & 4.9 & 23.0 & 5.4 & 12.0 & 4.0 \\
\hline 2 & 23.0 & 4.6 & 22.0 & 5.2 & 23.0 & 5.4 & 11.0 & 3.5 \\
\hline 3 & 28.0 & 6.2 & 23.0 & 5.3 & 25.0 & 6.4 & 8.0 & 2.5 \\
\hline 4 & 23.0 & 4.8 & 22.0 & 5.6 & 23.0 & 5.3 & 10.0 & 2.8 \\
\hline 5 & 22.0 & 5.1 & 23.0 & 5.5 & 21.0 & 7.5 & 13.0 & 3.6 \\
\hline 6 & 25.0 & 8.3 & 23.0 & 5.7 & 25.0 & 5.8 & 10.0 & 3.2 \\
\hline 7 & 26.0 & 6.0 & 23.0 & 5.2 & 23.0 & 5.1 & 8.0 & 2.6 \\
\hline 8 & 24.0 & 4.2 & 23.0 & 6.5 & 23.0 & 6.3 & 10.0 & 3.0 \\
\hline 9 & 19.0 & 2.6 & 23.0 & 6.5 & 25.0 & 5.4 & 8.0 & 2.5 \\
\hline 10 & 24.0 & 3.4 & 23.0 & 5.2 & 25.0 & 6.8 & 13.0 & 3.6 \\
\hline Average: & 23.9 & 5.0 & 23.0 & $\overline{5.6}$ & 23.6 & 5.9 & 10.3 & 3.1 \\
\hline Std. Deviation: & 2.4 & 1.6 & 0.8 & 0.5 & 1.3 & 0.8 & 1.9 & 0.5 \\
\hline
\end{tabular}

\begin{tabular}{|c|c|c|c|c|c|c|c|c|}
\hline Site Identification: & \multicolumn{8}{|c|}{$\mathrm{BH}-2$} \\
\hline Date: & \multirow{4}{*}{\multicolumn{2}{|c|}{$\begin{array}{c}\text { 1-Apr } \\
1600 \\
\text { Wooded } \\
\text { South } \\
\end{array}$}} & \multirow{4}{*}{\multicolumn{2}{|c|}{$\begin{array}{c}\text { 4-Apr } \\
1450 \\
\text { Wooded } \\
\text { South }\end{array}$}} & \multirow{4}{*}{\multicolumn{2}{|c|}{$\begin{array}{c}\text { 6-Apr } \\
1444 \\
\text { Wooded } \\
\text { South } \\
\end{array}$}} & \multirow{4}{*}{\multicolumn{2}{|c|}{$\begin{array}{c}\text { 10-Apr } \\
- \\
\text { Wooded } \\
\text { South }\end{array}$}} \\
\hline Start Time: & & & & & & & & \\
\hline Description: & & & & & & & & \\
\hline Slope Aspect: & & & & & & & & \\
\hline Measurement & Depth & $\mathrm{H}_{2} \mathrm{O}$ Eq. & Depth & $\mathrm{H}_{2} \mathrm{O}$ Eq. & Depth & $\mathrm{H}_{2} \mathrm{O}$ Eq. & Depth & $\mathrm{H}_{2} \mathrm{O}$ Eq. \\
\hline 1 & 27.0 & 5.8 & 26.0 & 5.5 & 27.0 & 6.3 & 24.0 & 7.0 \\
\hline 2 & 26.0 & 6.4 & 25.0 & 4.9 & 22.0 & 5.4 & 21.0 & 6.6 \\
\hline 3 & 28.0 & 6.0 & 25.0 & 5.5 & 16.0 & 5.3 & 21.0 & 7.0 \\
\hline 4 & 25.0 & 5.0 & 26.0 & 6.4 & 24.0 & 5.4 & 24.0 & 6.4 \\
\hline 5 & 26.0 & 5.8 & 25.0 & 6.0 & 26.0 & 6.6 & 23.0 & 6.0 \\
\hline 6 & 25.0 & 5.7 & 26.0 & 5.7 & 26.0 & 6.1 & 24.0 & 6.1 \\
\hline 7 & 25.0 & 4.8 & 25.0 & 5.5 & 21.0 & 4.5 & 21.0 & 5.5 \\
\hline 8 & 25.0 & 5.3 & 27.0 & 5.7 & 26.0 & 5.9 & 20.0 & 5.2 \\
\hline 9 & 25.0 & 5.8 & 22.0 & 4.2 & 21.0 & 4.4 & 21.0 & 5.6 \\
\hline 10 & 26.0 & 4.6 & 23.0 & 6.0 & 16.0 & 4.1 & 19.0 & 6.2 \\
\hline Average: & 25.8 & 5.5 & 25.0 & 5.5 & 22.5 & 5.4 & 21.8 & 6.2 \\
\hline Std. Deviation: & 1.0 & 0.6 & 1.5 & 0.6 & 4.1 & 0.8 & 1.8 & 0.6 \\
\hline
\end{tabular}


Appendix B. Measured snow depths and water equivalents for selected sites, Fairbanks, Alaska, jpring 1995--Continued

[Snow depth and water equivalent $\left(\mathrm{H}_{2} \mathrm{O}\right.$ Eq.) values in inches; a measurement of 0.0 indicates bare ground; --, no data; std. deviation, standard deviation]

\begin{tabular}{|c|c|c|c|c|c|c|c|c|}
\hline Site Identification: & \multicolumn{4}{|c|}{$\mathrm{BH}-2$} & \multicolumn{4}{|c|}{$\mathrm{BH}-3$} \\
\hline Jate: & \multirow{4}{*}{\multicolumn{2}{|c|}{$\begin{array}{l}\text { 17-Apr } \\
1628 \\
\text { Wooded } \\
\text { South }\end{array}$}} & \multirow{4}{*}{\multicolumn{2}{|c|}{$\begin{array}{l}\text { 25-Apr } \\
1533 \\
\text { Wooded } \\
\text { South }\end{array}$}} & \multirow{4}{*}{\multicolumn{2}{|c|}{$\begin{array}{c}\text { 4-Apr } \\
1521 \\
\text { Wooded } \\
\text { South }\end{array}$}} & \multirow{4}{*}{\multicolumn{2}{|c|}{$\begin{array}{c}\text { 10-Apr } \\
- \\
\text { Wooded } \\
\text { South }\end{array}$}} \\
\hline Start Time: & & & & & & & & \\
\hline Jescription: & & & & & & & & \\
\hline S̀lope Aspect: & & & & & & & & \\
\hline Measurement & Depth & $\mathrm{H}_{2} \mathrm{O} \mathrm{Eq}$. & Depth & $\mathrm{H}_{2} \mathrm{O} \mathrm{Eq}$. & Depth & $\mathrm{H}_{2} \mathrm{O} \mathrm{Eq}$ & Depth & $\mathrm{H}_{2} \mathrm{O} \mathrm{Eq}$. \\
\hline 1 & 16.0 & 4.3 & 2.0 & 0.6 & 23.0 & 5.8 & 20.0 & 5.1 \\
\hline 2 & 15.0 & 4.3 & 1.2 & 0.3 & 21.0 & 3.9 & 19.0 & 4.9 \\
\hline 3 & 13.0 & 3.6 & 2.4 & 0.7 & 21.0 & 4.5 & 22.0 & 4.9 \\
\hline 4 & 16.0 & 5.1 & 0.0 & 0.0 & 22.0 & 5.1 & 20.0 & 5.3 \\
\hline 5 & 16.0 & 5.0 & 0.0 & 0.0 & 21.0 & 6.0 & 21.0 & 6.5 \\
\hline 6 & 15.0 & 4.7 & 0.0 & 0.0 & 22.0 & 5.5 & 20.0 & 5.7 \\
\hline 7 & 13.0 & 4.3 & 0.0 & 0.0 & 20.0 & 5.3 & 21.0 & 5.3 \\
\hline 8 & 12.0 & 4.0 & 0.0 & 0.0 & 23.0 & 5.9 & 21.0 & 6.0 \\
\hline 9 & 13.0 & 4.2 & 0.0 & 0.0 & 19.0 & 5.3 & 21.0 & 5.4 \\
\hline 10 & 9.0 & 2.6 & 0.0 & 0.0 & 21.0 & 4.7 & 20.0 & 5.1 \\
\hline Average: & 13.8 & 4.2 & 0.6 & 0.2 & 21.3 & 5.2 & 20.5 & 5.4 \\
\hline Std. Deviation: & 2.2 & 0.7 & 0.9 & 0.3 & 1.3 & 0.7 & 0.8 & 0.5 \\
\hline
\end{tabular}

\begin{tabular}{|c|c|c|c|c|c|c|c|c|}
\hline \multirow{5}{*}{$\begin{array}{l}\text { Site Identification: } \\
\text { Jate: } \\
\text { Start Time: } \\
\text { Jescription: } \\
\text { Slope Aspect: }\end{array}$} & \multirow{2}{*}{\multicolumn{2}{|c|}{$\begin{array}{l}\text { BH-3 } \\
\text { 17-Apr }\end{array}$}} & \multicolumn{6}{|c|}{ BR-1 } \\
\hline & & & \multicolumn{2}{|c|}{ 1-Apr } & \multicolumn{2}{|c|}{ 4-Apr } & \multicolumn{2}{|c|}{ 10-Apr } \\
\hline & \multicolumn{2}{|c|}{1542} & \multicolumn{2}{|c|}{1452} & \multicolumn{2}{|c|}{1100} & \multicolumn{2}{|c|}{-} \\
\hline & \multirow{2}{*}{\multicolumn{2}{|c|}{$\begin{array}{l}\text { Wooded } \\
\text { South }\end{array}$}} & \multirow{2}{*}{\multicolumn{2}{|c|}{$\begin{array}{l}\text { Open } \\
\text { North }\end{array}$}} & \multirow{2}{*}{\multicolumn{2}{|c|}{$\begin{array}{l}\text { Open } \\
\text { North }\end{array}$}} & \multirow{2}{*}{\multicolumn{2}{|c|}{$\begin{array}{l}\text { Open } \\
\text { North }\end{array}$}} \\
\hline & & & & & & & & \\
\hline Measurement & Depth & $\mathrm{H}_{2} \mathrm{O}$ Eq. & Depth & $\mathrm{H}_{2} 0 \mathrm{Eq}$. & Depth & $\mathrm{H}_{2} 0 \mathrm{Eq}$. & Depth & $\mathrm{H}_{2} \mathrm{O} \mathrm{Eq}$. \\
\hline 1 & 12.0 & 4.0 & 27.0 & 5.6 & 25.0 & 5.2 & 19.0 & 5.4 \\
\hline 2 & 11.0 & 3.5 & 28.0 & 6.1 & 25.0 & 5.5 & 20.0 & 6.2 \\
\hline 3 & 8.0 & 2.5 & 26.0 & 5.4 & 27.0 & 5.7 & 19.0 & 5.4 \\
\hline 4 & 10.0 & 2.8 & 27.0 & 5.8 & 27.0 & 6.0 & 19.0 & 5.7 \\
\hline 5 & 13.0 & 3.6 & 28.0 & 6.1 & 23.0 & 5.4 & 21.0 & 6.6 \\
\hline 6 & 10.0 & 3.2 & 28.0 & 6.2 & 26.0 & 5.8 & 25.0 & 6.2 \\
\hline 7 & 8.0 & 2.6 & 28.0 & 6.2 & 25.0 & 5.5 & 25.0 & 6.8 \\
\hline 8 & 10.0 & 3.0 & 28.0 & 6.0 & 24.0 & 5.8 & 25.0 & 6.6 \\
\hline 9 & 8.0 & 2.5 & 25.0 & 6.1 & 26.0 & 6.1 & 23.0 & 5.0 \\
\hline 10 & 13.0 & 3.6 & 26.0 & 6.0 & 25.0 & 6.0 & 19.0 & 5.1 \\
\hline Average: & 10.3 & 3.1 & 27.1 & 5.9 & 25.3 & 5.7 & 21.5 & 5.9 \\
\hline Std. Deviation: & 1.9 & 0.5 & 1.1 & 0.3 & 1.3 & 0.3 & 2.7 & 0.7 \\
\hline
\end{tabular}


Appendix B. Measured snow depths and water equivalents for selected sites, Fairbanks, Alaska, Spring 1995--Continued

[Snow depth and water equivalent $\left(\mathrm{H}_{2} \mathrm{O}\right.$ Eq.) values in inches; a measurement of 0.0 indicates bare ground; --, no data; std. deviation, standard deviation]

\begin{tabular}{|c|c|c|c|c|c|c|c|c|}
\hline Site Identification: & \multicolumn{2}{|c|}{ BR-1 } & \multicolumn{6}{|c|}{ BR-2 } \\
\hline Date: & \multicolumn{2}{|c|}{ 18-Apr } & \multicolumn{2}{|c|}{ 1-Apr } & \multicolumn{2}{|c|}{ 4-Apr } & \multicolumn{2}{|c|}{ 10-Apr } \\
\hline Start Time: & \multicolumn{2}{|c|}{1552} & \multicolumn{2}{|c|}{1508} & \multicolumn{2}{|c|}{1128} & \multicolumn{2}{|c|}{-} \\
\hline Description: & \multicolumn{2}{|c|}{ Open } & \multicolumn{2}{|c|}{ Brush } & \multicolumn{2}{|c|}{ Brush } & \multicolumn{2}{|c|}{ Brush } \\
\hline Slope Aspect: & \multicolumn{2}{|c|}{ North } & \multicolumn{2}{|c|}{ Level } & \multicolumn{2}{|c|}{ Level } & \multicolumn{2}{|c|}{ Level } \\
\hline Measurement & Depth & $\mathrm{H}_{2} \mathrm{O}$ Eq. & Depth & $\mathrm{H}_{2} \mathrm{O} \mathrm{Eq}$. & Depth & $\mathrm{H}_{2} \mathrm{O} \mathrm{Eq}$. & Depth & $\mathrm{H}_{2} \mathrm{O} \mathrm{Eq}$. \\
\hline 1 & 9.0 & 2.7 & 24.0 & 4.9 & 22.0 & 5.3 & 21.0 & 5.7 \\
\hline 2 & 9.0 & 2.6 & 25.0 & 6.0 & 20.0 & 5.6 & 19.0 & 4.0 \\
\hline 3 & 8.0 & 2.2 & 27.0 & 6.1 & 11.0 & 3.4 & 22.0 & 4.8 \\
\hline 4 & 12.0 & 3.5 & 22.0 & 5.0 & 22.0 & 6.0 & 19.0 & 4.7 \\
\hline 5 & 10.0 & 2.9 & 17.0 & 4.1 & 20.0 & 5.3 & 26.0 & 6.1 \\
\hline 6 & 13.0 & 2.6 & 20.0 & 4.1 & 25.0 & 6.5 & 15.0 & 3.7 \\
\hline 7 & 7.0 & 1.7 & 18.0 & 3.9 & 22.0 & 5.5 & 14.0 & 3.5 \\
\hline 8 & 5.0 & 1.2 & 18.0 & 3.7 & 22.0 & 6.2 & 26.0 & 5.8 \\
\hline 9 & 8.0 & 2.3 & 14.0 & 3.4 & 24.0 & 6.2 & 23.0 & 5.8 \\
\hline 10 & 8.0 & 2.1 & 13.0 & 3.7 & 24.0 & 6.9 & 25.0 & 5.7 \\
\hline Average: & 8.9 & 2.4 & 19.8 & 4.5 & 21.2 & 5.7 & 21.0 & 5.0 \\
\hline Std. Deviation: & 2.3 & 0.6 & 4.7 & 1.0 & 3.9 & 1.0 & 4.3 & 1.0 \\
\hline
\end{tabular}

\begin{tabular}{|c|c|c|c|c|c|c|c|c|}
\hline \multirow{5}{*}{$\begin{array}{l}\text { Site Identification: } \\
\text { Date: } \\
\text { Start Time: } \\
\text { Description: } \\
\text { Slope Aspect: }\end{array}$} & \multirow{2}{*}{\multicolumn{2}{|c|}{$\begin{array}{c}\text { BR-2 } \\
\text { 18-Apr }\end{array}$}} & \multicolumn{6}{|c|}{$\mathrm{HC}-1$} \\
\hline & & & \multirow{4}{*}{\multicolumn{2}{|c|}{$\begin{array}{c}1-A p r \\
1410 \\
\text { Wooded } \\
\text { West }\end{array}$}} & \multirow{4}{*}{\multicolumn{2}{|c|}{$\begin{array}{c}\text { 4-Apr } \\
1142 \\
\text { Wooded } \\
\text { West }\end{array}$}} & \multirow{4}{*}{\multicolumn{2}{|c|}{$\begin{array}{c}\text { 10-Apr } \\
\text { - } \\
\text { Wooded } \\
\text { West }\end{array}$}} \\
\hline & & & & & & & & \\
\hline & & & & & & & & \\
\hline & & & & & & & & \\
\hline Measurement & Depth & $\mathrm{H}_{2} \mathrm{O}$ Eq. & Depth & $\mathrm{H}_{2} \mathrm{O} \mathrm{Eq}$. & Depth & $\mathrm{H}_{2} \mathrm{O} \mathrm{Eq}$. & Depth & $\mathrm{H}_{2} 0 \mathrm{Eq}$. \\
\hline 1 & 13.0 & 3.6 & 20.0 & 4.2 & 16.0 & 3.6 & 15.0 & 4.5 \\
\hline 2 & 17.0 & 5.1 & 20.0 & 4.4 & 17.0 & 4.2 & 16.0 & 7.2 \\
\hline 3 & 0.0 & 0.0 & 19.0 & 4.0 & 20.0 & 4.7 & 16.0 & 4.9 \\
\hline 4 & 15.0 & 4.6 & 21.0 & 5.1 & 19.0 & 4.9 & 16.0 & 4.4 \\
\hline 5 & 7.0 & 2.4 & 17.5 & 3.8 & 17.0 & 5.0 & 13.0 & 4.4 \\
\hline 6 & 8.0 & 2.5 & 17.0 & 4.1 & 20.0 & 4.9 & 12.0 & 3.6 \\
\hline 7 & 10.0 & 2.0 & 20.0 & 4.6 & 15.0 & 3.5 & 12.0 & 3.4 \\
\hline 8 & 6.0 & 1.7 & 20.0 & 4.7 & 14.0 & 3.7 & 10.0 & 2.5 \\
\hline 9 & 17.0 & 5.6 & 20.0 & 5.0 & 19.0 & 4.5 & 11.0 & 3.1 \\
\hline 10 & 17.0 & 5.4 & 16.5 & 5.0 & 14.0 & 3.8 & 10.0 & 2.7 \\
\hline Averaqe: & 11.0 & 3.3 & 19.1 & 4.5 & 17.1 & 4.3 & 13.1 & 4.1 \\
\hline Std. Deviation: & 5.8 & 1.9 & 1.5 & 0.5 & 2.3 & 0.6 & 2.5 & 1.4 \\
\hline
\end{tabular}


Appendix B. Measured snow depths and water equivalents for selected sites, Fairbanks, Alaska, Spring 1995--Continued

[Snow depth and water equivalent $\left(\mathrm{H}_{2} \mathrm{O}\right.$ Eq.) values in inches; a measurement of 0.0 indicates bare ground; --, no data; std. deviation, standard deviation]

\begin{tabular}{|c|c|c|c|c|c|c|c|c|}
\hline Site Identification: & \multirow{2}{*}{\multicolumn{2}{|c|}{$\begin{array}{c}\text { HC-1 } \\
\text { 18-Apr }\end{array}$}} & \multicolumn{6}{|c|}{$\mathrm{HC}-2$} \\
\hline Date: & & & \multicolumn{2}{|c|}{ 1-Apr } & \multicolumn{2}{|c|}{ 4-Apr } & \multicolumn{2}{|c|}{ 10-Apr } \\
\hline Start Time: & \multicolumn{2}{|c|}{1618} & \multicolumn{2}{|c|}{1432} & \multicolumn{2}{|c|}{1153} & \multicolumn{2}{|c|}{-} \\
\hline Description: & \multirow{2}{*}{\multicolumn{2}{|c|}{$\begin{array}{c}\text { Wooded } \\
\text { West }\end{array}$}} & \multirow{2}{*}{\multicolumn{2}{|c|}{$\begin{array}{c}\text { Wooded } \\
\text { West }\end{array}$}} & \multirow{2}{*}{\multicolumn{2}{|c|}{$\begin{array}{c}\text { Wooded } \\
\text { West }\end{array}$}} & \multirow{2}{*}{\multicolumn{2}{|c|}{$\begin{array}{l}\text { Wooded } \\
\text { West }\end{array}$}} \\
\hline Slope Aspect: & & & & & & & & \\
\hline Measurement & Depth & $\mathrm{H}_{2} \mathrm{O}$ Eq. & Depth & $\mathrm{H}_{2} \mathrm{O} \mathrm{Eq}$. & Depth & $\mathrm{H}_{2} \mathrm{O} \mathrm{Eq}$. & Depth & $\mathrm{H}_{2} \mathrm{O} \mathrm{Eq}$. \\
\hline 1 & 10.0 & 3.2 & 22.0 & 5.3 & 19.0 & 4.7 & 15.0 & 4.6 \\
\hline 2 & 8.0 & 2.8 & 22.0 & 5.5 & 19.0 & 5.0 & 15.0 & 5.0 \\
\hline 3 & 8.0 & 3.1 & 20.0 & 5.0 & 19.0 & 5.0 & 16.0 & 5.2 \\
\hline 4 & 0.0 & 0.0 & 22.0 & 5.0 & 22.0 & 5.2 & 17.0 & 5.6 \\
\hline 5 & 6.0 & 1.8 & 24.0 & 5.8 & 19.0 & 5.0 & 19.0 & 5.7 \\
\hline 6 & 4.0 & 1.3 & 23.0 & 5.1 & 21.0 & 4.7 & 18.0 & 5.6 \\
\hline 7 & 6.0 & 2.0 & 24.0 & 6.1 & 17.0 & 4.4 & 15.0 & 4.7 \\
\hline 8 & 8.0 & 2.4 & 21.0 & 5.1 & 22.0 & 4.0 & 18.0 & 5.9 \\
\hline 9 & 7.0 & 2.1 & 23.0 & 5.4 & 18.0 & 5.0 & 15.0 & 4.9 \\
\hline 10 & 9.0 & 3.0 & 20.0 & 5.0 & 21.0 & 6.4 & 14.0 & 3.8 \\
\hline Average: & 6.6 & 2.2 & 22.1 & 5.3 & 19.7 & 4.9 & 16.2 & 5.1 \\
\hline Std. Deviation: & 2.9 & 1.0 & 1.5 & 0.4 & 1.7 & 0.6 & 1.7 & 0.6 \\
\hline
\end{tabular}

\begin{tabular}{|c|c|c|c|c|c|c|c|c|}
\hline $\begin{array}{l}\text { Site Identification: } \\
\text { Date: } \\
\text { Start Time: } \\
\text { Description: } \\
\text { Slope Aspect: }\end{array}$ & \multicolumn{2}{|c|}{$\begin{array}{c}\text { 18-Apr } \\
1632 \\
\text { Wooded } \\
\text { West } \\
\end{array}$} & & & & $\begin{array}{l}\text { V-1 } \\
\text { Apr }\end{array}$ & & \\
\hline Measurement & Depth & $\mathrm{H}_{2} \mathrm{O} \mathrm{Eq}$. & Depth & $\mathrm{H}_{2} \mathrm{O}$ Eq. & Depth & $\mathrm{H}_{2} \mathrm{O} \mathrm{Eq}$. & Depth & $\mathrm{H}_{2} \mathrm{O} \mathrm{Eq}$. \\
\hline 1 & 2.0 & 1.0 & 19.0 & 4.2 & 18.0 & 5.5 & 0.0 & 0.0 \\
\hline 2 & 7.0 & 2.1 & 25.0 & 4.5 & 16.0 & 3.4 & 0.0 & 0.0 \\
\hline 3 & 3.0 & 1.2 & 26.0 & 6.0 & 17.0 & 6.0 & 0.0 & 0.0 \\
\hline 4 & 9.0 & 2.9 & 25.0 & 5.2 & 16.0 & 5.2 & 0.0 & 0.0 \\
\hline 5 & 8.0 & 2.6 & 22.0 & 5.2 & 18.0 & 4.9 & 0.0 & 0.0 \\
\hline 6 & 6.0 & 1.7 & 26.0 & 6.7 & 17.0 & 7.4 & 0.0 & 0.0 \\
\hline 7 & 8.0 & 2.7 & 20.0 & 4.5 & 15.0 & 4.5 & 0.0 & 0.0 \\
\hline 8 & 0.0 & 0.0 & 22.0 & 4.6 & 16.0 & 5.1 & 0.0 & 0.0 \\
\hline 9 & 5.0 & 1.2 & 26.0 & 6.0 & 24.0 & 6.0 & 0.0 & 0.0 \\
\hline 10 & 8.0 & 2.3 & 26.0 & 6.0 & 21.0 & 5.9 & 0.0 & 0.0 \\
\hline Average: & 5.6 & 1.8 & 23.7 & 5.3 & 17.8 & 5.4 & 0.0 & 0.0 \\
\hline Std. Deviation: & 3.0 & 0.9 & 2.7 & 0.8 & 2.7 & 1.1 & 0.0 & 0.0 \\
\hline
\end{tabular}


Appendix B. Measured snow depths and water equivalents for selected sites, Fairbanks, Alaska, Spring 1995--Continued

[Snow depth and water equivalent $\left(\mathrm{H}_{2} \mathrm{O}\right.$ Eq.) values in inches; a measurement of 0.0 indicates bare ground; --, no data; std. deviation, standard deviation]

\begin{tabular}{|c|c|c|c|c|c|c|c|c|}
\hline Site Identification: & \multicolumn{8}{|c|}{ WW-2 } \\
\hline Date: & \multicolumn{2}{|c|}{ 4-Apr } & \multicolumn{2}{|c|}{ 6-Apr } & \multicolumn{2}{|c|}{ 10-Apr } & \multicolumn{2}{|c|}{ 18-Apr } \\
\hline Start Time: & \multicolumn{2}{|c|}{1334} & \multicolumn{2}{|c|}{1529} & \multicolumn{2}{|c|}{-} & \multicolumn{2}{|c|}{1645} \\
\hline Description: & \multicolumn{2}{|c|}{ Bog } & \multicolumn{2}{|c|}{ Bog } & \multicolumn{2}{|c|}{ Bog } & \multicolumn{2}{|c|}{ Bog } \\
\hline Slope Aspect: & & & & & & & & \\
\hline Measurement & Depth & $\mathrm{H}_{2} \mathrm{O} \mathrm{Eq}$. & Depth & $\mathrm{H}_{2} \mathrm{O}$ Eq. & Depth & $\mathrm{H}_{2} 0 \mathrm{Eq}$. & Depth & $\mathrm{H}_{2} \mathrm{O} \mathrm{Eq}$. \\
\hline 1 & 24.0 & 5.1 & 16.0 & 4.4 & 17.0 & 4.7 & 7.0 & 2.3 \\
\hline 2 & 20.0 & 3.9 & 19.0 & 5.2 & 19.0 & 4.4 & 4.0 & 1.5 \\
\hline 3 & 22.0 & 5.2 & 19.0 & 5.1 & 15.0 & 4.4 & 0.0 & 0.0 \\
\hline 4 & 21.0 & 5.1 & 20.0 & 6.2 & 12.0 & 3.5 & 4.0 & 1.4 \\
\hline 5 & 19.0 & 5.2 & 13.0 & 3.5 & 12.0 & 3.5 & 0.0 & 0.0 \\
\hline 6 & 18.0 & 4.3 & 17.0 & 4.8 & 8.0 & 2.4 & 4.0 & 0.8 \\
\hline 7 & 12.0 & 3.3 & 19.0 & 5.1 & 7.0 & 2.4 & 4.0 & 1.0 \\
\hline 8 & 20.0 & 4.7 & 20.0 & 6.1 & 11.0 & 3.0 & 0.0 & 0.0 \\
\hline 9 & 17.0 & 4.4 & 20.0 & 4.8 & 10.0 & 3.1 & 3.0 & 0.8 \\
\hline 10 & 19.0 & 4.7 & 11.0 & 2.4 & 10.0 & 3.2 & 6.0 & 1.6 \\
\hline Average: & 19.2 & $\overline{4.6}$ & 17.4 & 4.8 & 12.1 & 3.5 & 3.2 & 0.9 \\
\hline Std. Deviation: & 3.2 & 0.6 & 3.2 & 1.1 & 3.8 & 0.8 & 2.5 & 0.8 \\
\hline
\end{tabular}

